\title{
Like my parents at home? Gender differences in childrens' housework in Germany and Spain
}

\author{
J. Ignacio Gimenez-Nadal \\ University of Zaragoza and CTUR
}

\author{
Jose Alberto Molina \\ University of Zaragoza and IZA
}

\author{
Raquel Ortega \\ University of Zaragoza
}

\begin{abstract}
This paper analyzes the relationship between parents' time devoted to housework and the time devoted to housework by their children. Using data for Germany and Spain from the Multinational Time Use Study, we find positive correlations between parents' and children's housework time, indicating that the more time parents devote to housework, the more time their children devote to housework. However, we find cross-country differences in these relationships. In Germany, both fathers' and mothers' housework is positively related to the time devoted to housework by their children, while in Spain this relationship only holds for fathers' time. We also find that these results are not applicable to all sub-groups of the population, as our analysis considering the labor force status and education of the parents yields mixed results.
\end{abstract}

JEL CODES: J16, J22

KEYWORDS: Housework, Children, Time Use

\footnotetext{
* We are very grateful for helpful comments from the editor and the three anonymous referees. This paper was partially written while Jose Alberto Molina was Visiting Fellow at the Department of Economics of Boston College (US), to which he would like to express his thanks for the hospitality and facilities provided. This paper has benefited from funding from the Spanish Ministry of Economics (Project ECO2012-34828).

Correspondence to: J. I. Giménez-Nadal, Department of Economic Analysis, Faculty of Economics, C/ Gran Via 2. 50005 Zaragoza, Spain. Email: ngimenez@unizar.es.
} 


\section{Introduction}

In this paper, we examine the relationship between the time devoted to housework by parents and that by their children, for a sample of families from Germany and Spain. Housework time in developed countries has been extensively analyzed (Gershuny, 2000; Gauthier, Smeeding and Furnstenberg, 2004; Sevilla et al., 2010; Gimenez-Nadal and Sevilla, 2012), and two robust empirical findings have been obtained: 1) women specialize in household tasks, as women devote comparatively more time to housework than men (Gershuny, 2000; Gauthier, Smeeding and Furnstenberg, 2004; Sevilla et al., 2010; Gimenez-Nadal and Sevilla, 2012), and 2) women concentrate on routine and more time-intensive housework, such as cooking and cleaning, whereas men are more active in sporadic, less time-intensive tasks, such as gardening and repairs (Cohen, 1998; Hersch and Stratton, 2002; Sevilla, Gimenez-Nadal and Fernandez, 2010; Fisher and Robinson, 2011; Grossbard, Gimenez-Nadal and Molina, 2014). Thus, attitudes towards the gender distribution of household labor appear to be transmitted from generation to generation, given the common patterns found in most countries and the stability of such patterns. Under this framework, we can presumably expect transmissions of preferences, values, and/or social behaviors about the use of time between generations (Gimenez-Nadal; Molina and $\mathrm{Zu}, 2014$ ), consistent with prior research analyzing the transmission of beliefs/preferences (Bisin and Verdier 2000; Bisin et al. 2004; Fernández, Fogli and Olivetti, 2004; Doepke and Zilibotti, 2012; 2014) and social norms (Carroll, Rhee and Thee, 1994, 1998; Farré and Vella, 2013), factors that are likely to affect how individuals allocate their time.

However, the literature on the intergenerational transmission of the uses of time is quite scarce (Cunningham, 2001; Bianchi et al., 2006; Cardoso, Fontainha and Monfardini, 2010; Alvarez and Miles, 2012; Gimenez-Nadal, Molina and Zu, 2014; Solaz and Wolff, 2015), despite the significance of the analysis of housework time, representing as it does an important part of the daily life of individuals, and that certain household tasks are considered to generate low levels of "instant enjoyment" or "instant happiness" to individuals (Kahneman et al., 2004; Kahneman and Krueger, 2006; Krueger, 2007; Gimenez-Nadal and Molina, 2015). An inegalitarian distribution of housework time may lead to inequalities in the wellbeing of individuals, as shown by Gimenez-Nadal and Sevilla (2011), and the relationship between parents' and children's housework times is an important factor in wellbeing. If we are able to identify how children's housework time is affected by parents' beliefs, preferences, or attitudes, public policies aimed at decreasing differences in wellbeing could be better 
oriented to reduce such differences.

We find positive correlations between parents and children in terms of their participation in and time devoted to housework, indicating that the more time parents devote to housework, the more participation in housework and the more time their children devote to housework. We do find gender differences in these relationships, and while in Germany both fathers' and mothers' housework is positively related to the participation in and the time devoted to housework by the children, in Spain this relationship only holds for fathers' time. Considering participation in housework time, in Germany a one-hour increase in the time devoted to housework by fathers is associated with increases of $21 \%$ and $18 \%$ in the probability of housework participation by sons and daughters, respectively, while a one-hour increase in the time devoted to housework by mothers is associated with an increase of $14 \%$ in the probability of housework participation by daughters. However, in the case of Spain, mothers' housework time yields no association with housework participation of children, while a onehour increase in the time devoted to housework by fathers is associated with increases of $24 \%$ and $17 \%$ in the probability of housework participation by sons and daughters, respectively.

Looking at the intensive margin, in Germany, a $10 \%$ increase in the time devoted to housework by fathers is associated with increases of $1.3 \%$ and $1 \%$ in the time devoted to housework by sons and daughters, respectively, while a $10 \%$ increase in the time devoted to housework by mothers is associated with an increase of $1.2 \%$ in the time devoted to housework by daughters. However, in the case of Spain, mothers' housework time yields no association with housework time of children, and a 10\% increase in the time devoted to housework by fathers is associated with increases of $1.2 \%$ and $0.4 \%$ in the probability of housework participation by sons and daughters, respectively. Thus, while mothers' housework time is associated with more time in housework by daughters in Germany, this is not the case for Spain.

Our contribution to the literature is twofold. First, we add to the existing research on intergenerational transmission of behaviours and attitudes. Despite the volume of research on intergenerational transmission of values (Wilhelm et al., 2008; Gronhoj and Thogersen, 2009; Bulte and Horan, 2011; Dohmen et al., 2012), happiness (Winkelman, 2005; Clair, 2012; Carlsson et al., 2014) and economic outcomes (Solon, 1999, 2002, 2004; Anger and Heineck, 2010; Black and Devereux, 2011; Holmlund, Lindahl and Plug, 2011; Anger, 2012; Tsou. Liu and Hammitt, 2012; Corak, 2013; Stella, 2013), few papers have directly analyzed intergenerational transmission in the uses of time (Álvarez and Miles, 2012; Gimenez-Nadal, 
Molina and Zhu, 2014; Solaz and Wolff, 2015). To the extent that housework time represents a significant portion of daily life, especially for women, this paper focuses on an important issue. Second, our paper builds on recent cross-country studies, such as Burda, Hammermesh and Weil (2008), Gershuny (2009), Gauthier, Smeeding, and Furstenberg (2004), and Gimenez-Nadal and Sevilla (2012), which have generally analyzed the uses of time in a variety of developed economies. We extend these cross-country comparisons by documenting for the first time the time devoted to housework by European youth, with a focus on crosscountry differences in social/gender roles.

The rest of the paper is organized as follows. Section 2 sets a background and a theoretical framework based on prior results. Section 3 describes the data and Section 4 the empirical strategy. Section 5 presents our empirical results, and Section 6 sets out our main conclusions.

\section{Background}

First, we must acknowledge that the institutional, economic, and residential status of youth in the two countries differ significantly. Considering the age at which young people leave the parental home, while the percentage of those aged 25-34 living with their parents is $21.7 \%$ in Germany, it is $38.7 \%$ in Spain (EUROSTAT, 2013). ${ }^{1}$ Prior research has found large crosscountry differences in the age at which residential independency is established (Becker et al., 2010; Angelini, Laferrère and Pasini, 2011; Angelini and Laferrère, 2013), with culture and family ties being the factors shaping nest-leaving and geographical mobility decisions (Giuliano, 2007; Alesina and Giuliano, 2010). Also, the economic status is different between German and Spanish youngsters, as the youth unemployment rates are greater in Spain than in Germany. According to EUROSTAT, while the unemployment rate for people under age 25 is $9.8 \%$ in Germany, in Spain that same unemployment rate is 22.2\% (EUROSTAT, 2015). The differences are even more striking for girls; specifically, the unemployment rates for boys under age 25 years are $11.7 \%$ and $18.5 \%$ in Germany and Spain, respectively, while the unemployment rates for girls under age 25 are $7.5 \%$ and $27.1 \%$ in Germany and Spain, respectively (EUROSTAT, 2015).

Access to housing is a further factor potentially affecting the decision of young people to leave home. The fact that in central and eastern Europe many young individuals get married

\footnotetext{
${ }^{1}$ Prior research has documented the adverse impact of delayed cohabitation on a number of children's outcomes, including individual motivations and ambitions, reservation wages, labor market entry, and geographical mobility (Billari and Tabellini, 2011).
} 
or cohabit while still living with their parents, illustrating the extent of housing problems in many countries (Billari, Philipov and Baizán, 2001). Some direct evidence is provided by the 2001 Eurobarometer survey, which asked young people why they did not move out of the parental home sooner. A substantial proportion of those aged 15-24 (especially in Spain) responded they could not afford to do so.

Among the mechanisms that can explain the associations between parents' and children's uses of time, three factors stand out: intergenerational transmission of preferences, parental role model, and imitation. In the case of the intergenerational transmission of preferences, the literature has shown that parents influence preference formation of the child (Wolfinger, 2000; Amato and DeBoer, 2001; Booth and Kee, 2009), in many cases through the culture of the country (Carroll et al.. 1994; Fernandez et al., 2004; Fernandez and Fogli, 2006, 2009; Giuliano, 2007). Regarding the parental role model, derived from the model of Akerlof and Kranton (2000) of gender identity, there exist gender norms about what a man or a woman should, or should not, do, with a social cost of deviating from the behaviors expected under these norms. Under these circumstances, parents may transmit these roles to their children so that they will conform to these social norms. However, it could be that children simply imitate their parents' behaviors, with a "doing by watching" attitude. If we consider a negative relationship between parents' and children's housework time, an exchange model (Becker, 1991) could be considered, according to which, the more time one of the household members devotes to housework, the less housework is left for the others.

Regarding the identification of the intergenerational transmission of attitudes or behaviors, Bisin and Verdier (2010) offer a recent survey of the economics of intergenerational cultural transmission, and Black and Deveraux (2011) review intergenerational mobility (i.e., transmission) of economic outcomes, such as earnings, employment, and education. Two methodologies have been used in prior research to identify intergenerational transmission of attitudes or behaviors. The first links the past behavior of the parents with the current behavior or attitudes of the children. Farré and Vella (2013) links the gender role attitudes of mothers in 1979 with that of their children in 1994, while Stella (2013) relates the acquisition of human capital by parents in the period 1920-1956 to the acquisition of human capital by their children when the latter become 50 years of age. The second approach analyzes the current values of both parents and children. For instance, Carlson et al. (2014) analyze subjective well-being among preadolescents and their parents, examining a range of measures, in the same period, for both parents and children. Hérault and Kalb (2015) analyze 
the correlation of labor market outcomes of parents and their children in Australia, using current values of parents and their children. The disadvantage of this second approach is that no causal effect can be found, as there may be both unmeasured factors and reverse causality issues that bias the coefficient estimates. Under this framework, we can only talk about intergenerational correlations.

We find very few studies for the specific case of intergenerational transmissions of timeuse behavior. Cunningham (2001) relates the parental division of labor when a son is growing, to the adult son's participation in routine housework once he marries, and shows that there is indeed a connection. Cardoso, Fontainha and Monfardini (2012) find positive evidence for France, Germany, and Italy of the link between time allocation by parents and by youngsters. Alvarez and Miles (2012), for a sample of Spanish families, find a significant positive correlation between a more egalitarian parental allocation of housework and a less asymmetrical distribution of domestic chores between sons and daughters. Solaz and Wolff (2015), for a sample of French couples, find a positive relationship between child's and parents' housework time. Gimenez-Nadal, Molina and Zu (2014), for the UK, show positive intergenerational correlations in housework for both parents, indicating that the more time parents devote to housework, the more time their children will devote to housework. Additionally, prior evidence has shown a gender differential in the intergenerational transmission of attitudes, as the association between mother (father) and son is different from the association between mother (father) and daughter (Alvarez and Miles, 2012; Solaz and Wolff, 2015).

One of the factors that seems to be transmitted from parents to children is that of gender/social norms (Farré and Vella, 2013), which also influences the time devoted to household tasks. For instance, Sevilla (2010) builds a composite index for measuring egalitarian social norms regarding the gender division of household tasks, and there appear to be differences across countries. Also, Gimenez-Nadal, Molina and Sevilla (2012) construct the average of the female-to-male ratio of childcare time as a measure of social norms regarding the household division of labor, and find cross-country differences regarding childcare time. According to Sevilla (2010), Germany ranks relatively low in comparison with Spain, but in Gimenez-Nadal, Molina and Sevilla (2012) Germany ranks comparatively high in comparison with Spain. Thus, it seems that there are differences in social/gender norms regarding the household distribution of household labor. Aliaga (2006) shows for a sample of people aged 20 to 74 in Germany and Spain that the ratio of male to female domestic work is 
0.53 and 0.30 , respectively, and thus we can consider that Germany has a more egalitarian gender distribution of household labor, which is related to more egalitarian social/gender roles of household labor.

Finally, institutional factors, such as welfare regimes, may also help to explain crosscountry differences in the correlations between parents' and children's housework time. Regarding welfare regimes, Gálvez-Muñoz, Rodríguez-Modroño and Domínguez-Serrano (2011) classify Germany in the group of countries with liberal systems, where state interventions are clearly subordinate to market mechanisms, while Spain is included in the group of Mediterranean countries with a strong "familialism", defined by the maintenance of intergenerational solidarity, weak institutional support for families, a dual labor-market model, and limited female access to the labor market. As a result, policies regarding the availability of public childcare services differ between the countries, and female labor-force participation rates are lower in Spain than in Germany (Boeri and Van Ours, 2008; GálvezMuñoz, Rodríguez-Modroño and Domínguez-Serrano, 2011). ${ }^{2}$ All these factors may influence how parents interact with their children, and how children observe the behavior of their parents, which in turn affects how behaviors are transmitted from parents to their children.

\section{Data}

We use the Multinational Time Use Study (MTUS), which is an ex-post harmonized crosstime, cross-national, comparative time use database, coordinated by the Centre for Time Use Research (CTUR) at the University of Oxford. ${ }^{3}$ It is constructed from national randomlysampled time-diary studies, with a common series of background variables, and total time spent in a range of activities (Gershuny, 2009). The MTUS provides us with information on individual time use, based on diary questionnaires in which individuals report their activities throughout the 24 hours of the day.

The MTUS includes 41 activities, defined as the 'primary' or 'main' activity individuals were engaged in at the time of the interview. Thus, we are able to add up the time devoted to any activity of reference (e.g., paid work, leisure, housework) as 'primary' activity. It is important to acknowledge that, in this paper, the fact that our analysis is based on the

\footnotetext{
${ }^{2}$ Boeri and Van Ours (2008) show that, at the time of the surveys, the percentage of children under age 3 using formal childcare facilities is $34 \%$ in the UK and $5 \%$ in Spain, indicating a significant difference in the availability of childcare services between the two countries

3 Information on the variables, and on how to access the data, is available on the MTUS website: http://www.timeuse.org/mtus. See Fisher, Gershuny and Gauthier (2011) for a full description of the MTUS documentation.
} 
comparison of a broad definition of housework provides a good basis from which to run meaningful comparisons across countries. As Gimenez-Nadal and Sevilla (2012) point out, however, the harmonization exercise by the CTUR team addresses differences in survey methodologies, such as different response rates (especially the lower response rate of some of the surveys), whether they covered, or not, the twelve months of the year, the sampling frame, and differences in activity codes. All the surveys provide weights designed to ensure that the surveys are nationally representative.

For the selection of countries, the availability of data limits our analysis, and prevents us from developing a more updated and general (e.g., with more countries) analysis. First, time use surveys are very scarce, in the sense that they are not done every year, but normally only every 5-6 years. Thus, there are no time use surveys for countries in all years. Second, time use surveys are developed with the minimum of resources, and in many cases these surveys are applied to only one member of the household, with multimember time use surveys being the exception and not the norm. Third, in the current version of the MTUS, the most actual multimember time use surveys are France (1998), Spain (2002 and 2009), Germany (2003) and the UK (2000). As the UK is analyzed in Gimenez-Nadal, Molina and Zu (2014), and France is analyzed by Solaz and Wolff (2015), we focus on Germany and Spain. Moreover, to analyze a period of time where the two countries are exposed to similar economic circumstances (economic conditions such as unemployment rates may affect the time devoted to housework (Gimenez-Nadal and Molina, 2014), we exclude 2009 for the case of Spain. The German survey includes 3 diaries per person, while the Spanish one includes one diary per person.

We select heterosexual couples with at least one child of 10 years or older in the household. The MTUS includes a variable that is related to the relationship of the individuals with the reference person, with the following options: "Person 1", "Spouse/Partner", "Child", "Parent", "Sibling", "Other relative" and "Not related". Based on this classification, we select parents (e.g., relationship is "person 1" or "Spouse/Partner") and their own children (i.e., relationship is "Child). With the current classification of the relationship between the members of the household, we cannot ascertain whether children are biological children, or whether either of the parents is a step-mother/father. The lower limit of 10 years of age for children is imposed by the technical characteristics of the surveys, as the two surveys include time use diaries for all members of the household who are 10 years or older, and thus we cannot analyze the uses of time for younger children. Furthermore, any child living with their 
parents is chosen, with no upper limit on their age, although we impose the requirement that the child is not married/does not live with her/his own partner, as this would add noise to the analysis, given the effect of a third party. ${ }^{4}$

After selecting our sample of parents and children, we observe that the mean age of children in Germany and Spain is different (16.03 vs. 21.09 years of age, respectively), a difference that may be partly explained by the different economic and residential status of the young people in Germany and Spain, previously explained in Section 2. But we cannot discard the issue of sample selection, as Spanish youths may choose to stay longer with parents because they benefit from more domestic comfort than living by themselves. ${ }^{5}$ To take this selection issue into account, in our empirical analysis we consider an alternative sample of youths aged between 11 and 18 to check the robustness of our results.

We consider the time devoted to housework by both parents and their children, measured in hours per day. ${ }^{6}$ Our definition of housework includes the total time devoted to the following activities: "cook, wash up", "housework", "odd jobs", "shopping” and "domestic travel". Table 1 shows the participation in and the time devoted to housework by children and their parents, by country. A first issue here is that the participation in and the time devoted to housework by sons is comparatively lower than that of daughters. In this sense, sons do housework in $68 \%$ and $52 \%$ of the diaries, and devote 0.95 and 0.66 hours to housework, in Germany and Spain, respectively, while daughters do housework in $83 \%$ and $80 \%$ of the diaries, and devote 1.44 and 1.56 hours to housework, in Germany and Spain, respectively.

\footnotetext{
${ }^{4}$ Separation has increased in Europe in recent decades, as shown by the increase of crude divorce rates in almost all countries (EUROSTAT, 2015). The fact that we do not choose monoparental families eliminates around $25 \%$ of the children. In the case of Germany, from 3,272 children, we choose 2,518 of these children, which represents a decrease of $23 \%$ of the sample. In the case of Spain, from 11,330 children, we choose 8,155 of these children, which represents a decrease of $28 \%$ in the sample. Focusing on households, for Germany and Spain the samples are reduced by $25 \%$ (from 2,115 households to 1,575 household) and 30\% (from 7,500 households to 5,244 households). However, we do not include monoparental households in our analysis, given that the share and the amount of housework done by each member can be different in these households.

${ }^{5}$ The characteristics or preferences of adult children still living with their parents may differ from the characteristics of those individuals not living with their parents. We have compared individuals in the same age range living (i.e., being a child of the reference person of the household) and not living with their parents (i.e., not being a child of the reference person of the household) in the two countries. We observe that individuals not living with their parents participate in and devote comparatively more time to housework activities, in some cases with a threefold difference (e.g., women in Spain). Furthermore, and in comparison with individuals living with their parents, individuals not living with their parents are older, have higher labor force participation and live in larger households. These differences may indicate that those living with their parents are able to enjoy a "better living". This evidence indicates that those children staying at home may want to benefit from their parents' input, having different preferences than those who decide to leave home. Thus, sample selection may be biasing our results, and the reported correlations can be seen as a lower bound, as we could expect a higher relationship once children leave home.

${ }^{6}$ The analysis of childcare time may be interesting, since it is one of the larger times that teenagers spend when they have younger siblings. Looking at the time devoted to childcare in the current data, $96.83 \%$ of the sample report no time in childcare activities, and given this low variation in childcare time we cannot analyze this activity. To the extent that children may not be doing childcare on a daily basis, it may be that the data at hand is not the best dataset to analyze this issue. We leave this analysis for future research.
} 
This higher participation and housework time of daughters compared to sons has also been reported in prior studies (Álvarez and Miles, 2012, Gimenez-Nadal, Molina and Zu, 2014; Solaz and Wolff, 2015). Regarding the time devoted to housework by parents, we find that fathers of sons and daughters in Spain devote a relatively smaller amount of time to housework (e.g, 1.45 and 1.32 hours per day) than fathers of sons and daughters in Germany (e.g, 2.04 and 2.02 hours per day). Conversely, mothers of sons and daughters in Spain devote more time to housework (e.g., 6.13 and 5.85 hours per day) compared to mothers of sons and daughters in Germany (e.g., 4.46 and 4.51 hours per day). These results are consistent with prior studies showing that, in Spain, there is a large gender gap in housework favoring women, which makes this country especially inegalitarian in the gender distribution of household labor (Sevilla, 2010; Sevilla, Gimenez-Nadal and Fernandez, 2010; GimenezNadal, Molina and Sevilla, 2012). Thus, our analysis includes countries with quite different social/gender norms (Burda et al., 2013), welfare regimes, and labor market structures, which is important in our analysis.

Focusing on the relationship between the time devoted to housework by parents and that of their children, we consider three concerns that may arise: 1) measurement error, 2) reverse causality, and 3) unobserved heterogeneity, all of which have been identified as sources of endogeneity. Regarding measurement error, the way time use information is collected from individuals can reduce the potential errors individuals may make when they recall the time devoted to the different activities throughout the day. One advantage of time-use surveys over stylized-questions, such as those included in the European Community Household Panel, the British Household Panel Survey, and the German Socioeconomic Panel (where respondents are asked how much time they have spent, for example, in the previous week, or normally spend each week, on market work or housework), is that diary-based estimates of time use are more reliable and accurate than estimates derived from direct questions (Juster and Stafford, 1985; Robinson, 1985; Robinson and Godbey, 1997; Bianchi et al., 2000; Bonke, 2005; YeeKan, 2008).

For instance, in the labor supply literature, Klevmarken (2005) argues that information on actual hours of work from time-use surveys is more relevant than the normal hours or contracted hours generally reported in stylized questions. Thus, in the same way that moneyexpenditure diaries have become the gold standard in the consumption literature, so have time-use diaries become the preferred method of gathering information on time spent on market work, non-market work, and leisure. Most studies documenting how individuals use 
their time are now based on these data sets (Aguiar and Hurst, 2007; Guryan, Hurst and Kearney, 2008; Gimenez-Nadal and Sevilla, 2012; Sevilla, Gimenez-Nadal and Gershuny, 2012). ${ }^{7}$ Similarly, measurement errors of the time devoted to housework by individuals are not likely to be a problem in the present study, since the fact that each respondent compiles his/her own diary reduces the probability that children's reporting is influenced by that of the parents.

Regarding reverse causality, the question here is whether the time devoted to housework by children depends on the time devoted to housework by their parents, while the time devoted to housework by the parents is not affected by the time devoted to housework by their children. If this is the case, the results of regressing the time devoted to housework by children on the time devoted to housework by their parents would be unbiased. However, if there also exists an effect of children's housework on the time devoted to housework by their parents, we would have reverse causality from this two-way relationship, and simple econometric models that do not take this into account would yield biased estimations. For instance, if one takes a very simple view of housework as a burdensome, routine activity that members of the household must perform, it may be that parents just do this activity as they must do, and this time is related to their children's housework time. But it may also be the case that families perform housework together as a means to bond and share intimacy (e.g., cook together as a way of spending quality time with one another). While in the first case, a one-way relationship would be expected, in the second case we would expect a two-way relationship. Under this framework, and with the data at hand, we cannot disentangle what is the direction of causality, and thus we acknowledge that our results must be taken with caution.

Finally, regarding the unobserved heterogeneity of individuals and households, this proves to be the most significant limitation of our analysis, as our data is a cross-section of individuals and we cannot take into account the unobserved heterogeneity of individuals and households. There may be unobserved factors at the individual and household level that correlate with both the children's time devoted to housework and that of their parents. Factors such as parents' heterogeneity in time preferences and in the outsourcing of household chores, heterogeneity in the productivity of individuals in housework, or differences in gender/social norms across countries, are just some examples of factors that can affect the time devoted to

\footnotetext{
${ }^{7}$ The MTUS has been widely used across the social sciences (Gershuny, 2000; Gershuny and Sullivan, 2003; Gauthier, Semmeding and Furstenberg, 2004; Guryan, Hurst and Kearney, 2008; Gershuny, 2009, Gimenez-Nadal and Sevilla-Sanz, 2011;2012; Gimenez-Nadal and Molina, 2013).
} 
housework by parents and their children. Despite we test the robustness of our results by using panel-data models, these results cannot be considered as general, and we cannot thus identify any causal effect of parents' housework time on children's housework time, but we can explore the correlational structure of the data. Unfortunately, there are no panels of timeuse surveys currently available.

\section{Empirical strategy}

In our analysis, we take into account how parents' time in housework relates to both the extensive (i.e., participation) and intensive (i.e., time) margins. Regarding participation in housework time of children, we define a dummy variable "participation" that takes value "1" if the reference son/daughter did any housework during the day of survey, and value " 0 " otherwise. With the aim of capturing the expected differential impacts of maternal and parental housework time on children's participation, depending on the gender of the parent and the children, we estimate our models separately by the gender of the child. We estimate a Probit model according to the following Equation:

$$
\operatorname{Pr}\left(\text { Participation }_{\mathrm{ih}}=1\right)=\Phi\left(\beta_{1} \operatorname{lnFather'sTime~}_{\mathrm{ih}}, \beta_{2} \operatorname{lnMother'sTime~}_{\mathrm{ih}}, \gamma \mathrm{X}_{\mathrm{ih}}\right)
$$

where $\Phi$ is the cumulative density function for the standard normal. The dependent variables do not follow a normal distribution, which makes the error terms of regressions nonhomoskedastic, and thus we correct our regressions by obtaining robust standard errors.

Furthermore, with the aim of analyzing the intensive margin of children's housework, we use an adaptation from Black and Devereux (2011) and Stella (2013), who studied human capital transfers, and we regress the time devoted to housework by children on the time devoted to housework by the father and mother of those children. In this sense, children's housework is linked to parents' housework, and thus the unit of observation is each childparent pair. With the aim of capturing the expected differential impacts of maternal and parental housework time on children's time, depending on the gender of the parent and the children, we estimate our models separately by the gender of the child. We estimate the following OLS model: ${ }^{8}$

\footnotetext{
${ }^{8}$ Given the significant rate of non-participation in housework time of children, if the number of non-participants differs greatly across countries or gender, tobit models are helpful as they take into account the distribution of non-participants. Thus, we have alternatively estimated tobit models on the (log of) time devoted to housework by children. Results obtained from tobit models are the same as the results obtained from OLS models, and given that OLS coefficients can be directly interpreted we follow OLS results. Results for tobit models can be found in Table A1 of online Appendix A.
} 


$$
\text { lnTime }_{\text {ih }}=\alpha+\beta_{1} \text { lnFather'sTime }_{\text {ih }}+\beta_{2} \text { lnMother'sTime }_{\text {ih }}+\gamma \mathrm{X}_{\mathrm{ih}}+\varepsilon_{\mathrm{ih}}
$$

where the dependent variable $\ln ^{\mathrm{Time}_{\text {in }}}$ denotes the log of the time devoted to housework by child " $i$ " in household " $h$ ", expressed as a linear function of (log) time dedicated to housework by parents. The coefficients $\beta_{1}$, and $\beta_{2}$ represent the elasticity of children's time with respect to their parents' time, with an elasticity of 0.5 indicating that a $10 \%$ difference between two families' time translates into an average difference of roughly $5 \%$ between their respective children's times. Although we use the logarithm of housework of parents and their children, the transformed variables do not follow a normal distribution, which makes the error terms of regressions non-homoskedastic, and thus we correct our regressions by obtaining robust standard errors. ${ }^{9}$

The set of socio-demographic variables $\mathrm{X}_{\text {in }}$ includes the children's characteristics (gender, age, and work status), parent's characteristics (age, education, work status) and household characteristics (household size, age of the youngest child of the household, whether the household owns the dwelling, the presence of any computer at home, and urban residence). We specifically include parents' ages to capture both differences in housework time behaviors across parental birth cohorts, and life-cycle effects (Apps and Rees, 2005). Day-of-the-week dummies are also included in order to scale the day of the week (ref.: Saturday). ${ }^{10}$ Finally, $\varepsilon_{\text {ih }}$ represents the robust standard error. Given that there are multiple observations per household, all standard errors in Equations (1) and (2) are clustered at the individual level to account for any intra-personal correlation.

One of the limitations of our study is that time use surveys are cross-sectional data, and thus we cannot identify correlations between parents' and children's housework time net of (permanent) individual and household heterogeneity in preferences. However, we now exploit the fact that, for Germany, we have three diaries per individual and thus we have a pseudopanel of time use diaries. Of these 3 diaries, one is assigned to the weekend (e.g., Saturday or Sunday) while the other 2 diaries are randomly assigned to the week days. Comparing the intra-personal and inter-personal variation of our dependent variable, we obtain an intrapersonal variation of 0.38 , while the inter-personal variation is 0.41 . Thus, we have sufficient

\footnotetext{
${ }^{9}$ See online Appendix B for a description of the distribution of housework time of parents and their children.

${ }^{10}$ Other variables of interest that could be included in our regressions are the use of a domestic help, the presence of a garden and the type of dwelling, as they would probably affect the time devoted to housework by children. However, this information is not available in the MTUS dataset (see the MTUS survey documentation)."
} 
intra-personal variation to apply a Fixed Effects estimator, where the panel data dimension is considered at the individual level. This Fixed Effects (FE) estimator - also known as the intraestimator - allows us to control for unobserved heterogeneity when this heterogeneity is constant over time, and takes a first difference of the explanatory variables, which removes any time-invariant components of the model. Thus, while the OLS estimator takes into account the current values of the variables, the FE estimator takes into account first differences of the variables and eliminates all the variables that hold constant over time.

We estimate the following equation using the FE estimator:

$$
\text { lnTime }_{\text {iht }}=\alpha_{\mathrm{i}}+\beta_{1} \text { lnFather'sTime }_{\text {iht }}+\beta_{2} \text { lnMother'sTime }_{\text {iht }}+\gamma \text { Day }_{\text {iht }}+\varepsilon_{\text {iht }}
$$

where the dependent variable ln Time $_{\text {int }}$ denotes the $\log$ of the time devoted to housework by child " $i$ " in household " $h$ " on day " $t$ " $(\mathrm{t}=1,2,3)$, with this being expressed as a linear function of $(\log )$ time on housework by parents in household " $h$ " of child " $i$ " on day " $t$ ". Given the short period of time, the socio-demographic characteristics of sons and daughters do not change over the period, and thus they are time-invariant. Thus, the FE eliminates all the sociodemographic characteristics, and the only time-variant variable here is the day when the diary was compiled, included in the regressions, and thus we take these results as complementary and not as main results, given that we cannot control for the observed heterogeneity of children and their parents.

Table 1 shows means and standard deviations for our explanatory variables. We observe that the average age of children is higher in Spain (17.11 and 16.31 years of age for sons and daughters in Germany, compared to 21.67 and 20.81 years of age for sons and daughters in Spain), indicating that children leave home later in Spain (Becker et al., 2010; Angelini, Laferrère and Pasina, 2011; Angelini and Laferrère, 2013). Furthermore, we observe that the percentage of unemployed children is higher in Spain (7\% of sons and 9\% of daughters) compared to Germany (around 1\% for both sons and daughters), also consistent with the lower economic status of Spanish children. Regarding parents' characteristics, we observe that, in both countries, the proportion of fathers with university education is greater than mothers, fathers are older, and have a higher probability of participation in the labor market, compared to mothers in all countries. Focusing on cross-country differences in household characteristics, the level of education of German parents is higher, they are younger, have a greater labor force participation - especially for mothers - the youngest child is older, and there is a higher proportion of having a computer present at home, in comparison with 
Spanish parents.

Figures 1 and 2 show the raw relationship between children and parents' housework times. The figures plot the average time devoted to housework by children for each time devoted to housework of the parent; that is, for all the households with the same amount of time devoted to housework by the father/mother, we average the time devoted to housework by the children, by gender and country. For instance, for all German households where the father devotes 1.04 hours to housework, we average the time devoted to housework by sons and daughters, obtaining a mean value of housework of 0.76 and 0.46 hours per day for daughters and sons, respectively. We then plot (scatter plot) mean housework time of sons/daughters (yaxis) on the time devoted to housework (x-axis) by fathers (Figure 1) and mothers (Figure 2). We have also added a linear fit to determine the extent to which scatters are distributed following a linear relationship.

We observe a positive relationship between the time devoted to housework by fathers, and the time devoted to housework by both sons and daughters. This raw relationship points to a positive relationship between fathers' and children's housework time, although we cannot ascertain whether this positive relationship is greater for sons than for daughters. In the case of mothers' housework time, we find mixed evidence for sons, and while we observe a positive association between mothers' housework time and the time devoted to housework by sons in Germany, we find a negative association between mothers' housework time and the time devoted to housework by sons in Spain. We find positive correlations between mothers and daughters' housework time in both Germany and Spain. Thus, while there appears to be a robust positive association between fathers' and children's housework time, there are crosscountry and gender differences in the relationship between mothers' and children's housework time, which clearly indicate the necessity to take into account the gender of the parent and the child in the regressions.

\section{Results}

Columns (1) and (3) of Table 2 show the result of estimating Equation (1) for sons and daughters in Germany, and Columns (5) and (7) show the result of estimating Equation (1) for sons and daughters in Spain. Columns (2) and (4) of Table 2 show the result of estimating Equation (2) for sons and daughters in Germany, and Columns (6) and (8) show the result of estimating Equation (2) for sons and daughters in Spain. We find positive correlations 
between parents' and children's participation in and time devoted to housework, indicating that the more time parents devote to housework, the higher participation and the more time their children devote to housework. This evidence is consistent with the hypothesis of the existence of intergenerational transmission of behavior regarding the time devoted to housework, as more housework time of the parents is related to more housework time of their children. However, we find cross-country and gender differences in these relationships, and while in Germany both fathers' and mothers' housework is positively related to the participation in and the time devoted to housework by daughters, in Spain it is only fathers' time in housework that is positively related. Comparing our results with prior research using other countries, Gimenez-Nadal, Molina and $\mathrm{Zu}$ (2014) find for the UK positive intergenerational correlations in housework for both parents, although a higher father-tomother housework ratio is positively related to a higher child-to-mother housework ratio, which may be interpreted as that the housework of parents takes a larger role in explaining the housework time of children. Solaz and Wolff (2015) use data for France and find a positive relationship between child and parental housework times, but a gendered effect of the intergenerational relationship is not systematically confirmed and depends on the type of domestic tasks.

In particular, and for the case of Germany, a one-hour increase in the time devoted to housework by fathers is associated with increases of $21 \%$ and $18 \%$ in the probability of housework participation of sons and daughters, respectively, while a one-hour increase in the time devoted to housework by mothers is associated with an increase of $14 \%$ in the probability of housework participation of daughters. However, in the case of Spain, mothers' housework time yields no association with housework participation of children, and a onehour increase in the time devoted to housework by fathers is associated with increases of $24 \%$ and $17 \%$ in the probability of housework participation of sons and daughters, respectively. Thus, while mothers' housework time is associated with a higher participation in housework of daughters in Germany, this is not the case for Spain. Furthermore, and comparing the coefficients of fathers and mothers' housework time on daughters' participation in housework for Germany, a t-type test indicates that the association is similar, and thus that the expected effect is similar.

Similar conclusions can be obtained if we look at the intensive margin (i.e., housework time of children). For the case of Germany, a $10 \%$ increase in the time devoted to housework by fathers is associated with increases of $1.3 \%$ and $1 \%$ in the time devoted to housework by 
sons and daughters, respectively, while a $10 \%$ increase in the time devoted to housework by mothers is associated with an increase of $1.2 \%$ in the time devoted to housework by daughters. However, in the case of Spain, mothers' housework time yields no association with housework time of children, and a $10 \%$ increase in the time devoted to housework by fathers is associated with increases of $1.2 \%$ and $0.4 \%$ in the probability of housework participation of sons and daughters, respectively. Thus, while mothers' housework time is associated with more time in housework by daughters in Germany, this is not the case for Spain. Furthermore, and comparing the coefficients of fathers and mothers' housework time on daughters' housework time, a t-type test indicates that the association is similar and thus that the expected effect is similar.

Focusing on cross-country differences, the differences between Germany and Spain may also indicate that gender roles, which are likely transmitted from parents to children, are different in Germany and Spain. In this sense, Aliaga (2006) shows that the gender gap in housework time (i.e., women devote comparatively more time to housework than men) is greater in Spain in comparison with Germany, which may reveal that women are supposed to bear a larger share of household responsibilities in Spain. Thus, it may be that in Spain gender roles establish household responsibilities as women's tasks, while men are not seen as being responsible for household management. Under this framework, if children observe that fathers devote more time to household labor, it can influence their behavior, while mother's housework has no such influence, since it is perceived as work that must be done by women. But in the case of Germany, the role of women within the household may not be so clearly defined, and participation of women in housework is not so commonly accepted, so that the more time mothers devote to housework the more time daughters devote to housework. Thus, we find a gendered difference in the intergenerational transmission of time use behaviors, since the association between mother (father) and son is different from the association between mother (father) and daughter, consistent with the existing literature (Alvarez and Miles, 2012; Solaz and Wolff, 2015).

Another factor that may influence the relationship between parents and children's housework time is employment regulations. In the current context, we have countries with large differences in labour market regulations, as labour markets are comparatively more regulated in Mediterranean countries, such as Spain, with strict rules governing the hiring and firing of workers, and the types of employment arrangements permitted, which results in women in Spain participating less in the labour market (Del Boca, 2002). Also, the rates of 
temporary and full-time contracts differ by country (EUROSTAT, 2015), And working conditions across European countries are different (Lucifora and Cotini, 2013). All these factors lead to cross-country differences in the labor force participation of women, consistent with our results in Table 1: while $74 \%$ of mothers in Germany work, only $38 \%$ of mothers in Spain participate in the labor market. Thus, while Spanish mothers mostly stay at home, this is not the case in Germany, and consequently the participation of German mothers in housework may have a larger effect on their children because this time could be considered as more sporadic.

For the rest of the factors, we observe that the age of the children, and being unemployed in Spain, is positively related with both participation in and time devoted to housework. Working full-time in Spain is negatively related to both participation in and time devoted to housework, and mothers' participation in the labor market is related to a higher participation in and more time devoted to housework in Spain and Germany.

Table 3 shows the results of estimating Equation (3) for Germany. We observe that fathers' and mothers' time in housework is positively related to the housework time of both sons and daughters, with these associations being statistically significant at standard levels. Comparing these results with previous results, we observe that now the coefficient of mothers' housework time on sons' housework time is statistically significant, while this was not the case for the results using the OLS model. Furthermore, the t-type test of comparison of coefficients for the results for daughter's housework time shows that the coefficient of mother's housework time is comparatively larger than that of father's housework. Thus, once we take the unobserved heterogeneity of individuals into account, we observe that mother's time increases in the importance of its relationship with children's housework time. For this reason, while the relationship between father's and children's housework time appears to be quite robust, as it does not depend on the unobserved heterogeneity of individuals, the relationship between mother's and children's housework time depends on unobserved factors, which may indicate that the latter relationship may be present in a certain type of family only. Also, it could be that sample selection is important in this context. Thus, in the rest of this Section we will focus on disentangling differences in the previously-reported relationships, depending on parents' characteristics and children's age.

We next analyze the relationship between parents' and children's housework time, considering that these relationships may vary depending on the economic status of the parents. For instance, it could be that, in those couples where one of the members does not 
participate in the labor market, that couple are comparatively more concerned about their children's behavior and well-being (i.e., single-earner couples have stronger preferences for raising their children by themselves). In this sense, we could expect different patterns of behavioral transmission, that is, stronger correlations of parents' housework with the housework of their children. However, it could also be the case that, in those couples where one of the members does not participate in the labor market, the non-working member has more available time and thus he/she does most of the housework, while the other members do less. For this reason, we consider the economic and labor status of parents to be a factor shaping the relationship between parents' and children's housework time.

First, we consider the labor status of the parents. This analysis is important to the extent that Spain has a lower Female Labor Force Participation (FLFP) rate than Germany (EUROSTAT, 2015). This could be a consequence of individual/household preferences for time in the labor market, and of the attitudes and behaviors they want to transmit to their children. In this sense, a lower FLFP could reflect a weaker preference for time in the labor market and a stronger preference towards the raising of children. We thus consider whether the parents participate in the labor market (two-earner households), or whether one of the parents only participates in the labor market. To the extent that, in one-earner couples, it is almost always women who do not participate, we consider male-earner households.

Panels A and B of Table 4 show the results of estimating Equations (1) and (2) for maleearner households, and two-earner households, respectively. We observe that the positive relationship between fathers' participation in and time devoted to housework, and the time devoted to housework by children remains positive in all cases. Thus, this relationship is robust to the economic situation of the couple. Furthermore, in the case of Spain, while for two-earner households it is only fathers' housework time that is related to children's housework time, in male-earner households, the mother's housework correlates with children's housework time, particularly, positively for sons. Thus, while in German twoearner households mother's participation in and time devoted to housework is positively related to son's and daughter's housework time, in Spanish two-earner households, mother's participation in and time devoted to housework is positively related to son's housework time.

A second factor that may condition the correlations observed in the analysis of all the couples is education. It could be that more educated parents are more concerned about the educational and attitudinal behavior of their children, as parents may consider they have attitudes and characteristics that are better, relative to the attitudes and characteristics of less 
educated parents. It could also be that, since more educated parents have a higher opportunity cost, they devote less time to housework, compared to lower educated parents, which negatively affects the positive correlation between parents' and children's housework time. Thus, we estimate Equations (1) and (2) considering three levels of education of the members of the couples: primary education (less than high school level), secondary education (high school level), and university education (more than high school level). ${ }^{11}$

Panels C, D and E of Table 4 shows the results of estimating Equation (1) for couples where the two members of the household have primary education, secondary education, and university education, respectively. We observe that, as the level of education of the couple increases, the relationship between the fathers' participation in and time devoted to housework, and the time devoted to housework by children strengthens. But in the case of mothers' participation in and time devoted to housework, and the time devoted to housework by children, only in highly educated couples in Germany is the relationship robust and statistically significant. These results may indicate that parents transmit gender roles through education, with highly educated parents being able to transmit their gender roles more easily. However, it has also been reported that there is a negative gradient between housework and education, and thus the effect on one additional unit of housework in couples with a low level of housework may be more important than the effect in couples with more time in housework. Furthermore, differences in education may lead to differences in productivities in housework time, which may also affect these relationships. Given the complexity of this issue, and the limitations of the data at hand, we leave this issue for future research.

Finally, we restrict the analysis to youngsters aged 11 to 18 , to ascertain the robustness of our results to sample selection issues. Table 5 shows the results of estimating Equations (1) and (2) for both Germany and Spain. We still find robust results on the relationship between fathers' participation in and time devoted to housework, and the time devoted to housework by children, as we find positive correlations in both Spain and Germany for boys and girls. In the case of mother's participation in and time devoted to housework, results are robust for Germany, but we now find that a higher participation in and time devoted to housework by mothers in Spain is positively related to son's and daughter's housework time, results that contrast with our earlier findings. Considering that our main results are based on an older sample in the two countries, the difference in results for Spain may lead to the conclusion that

\footnotetext{
${ }^{11}$ To the extent that there is positive assortative matching by education (Oppenheimer, 1988; Mare, 1991; Pencavel, 1998; Lewis and Oppenheimer, 2000; Blossfeld and Timm, 2003), we consider that parents have similar levels of education, and we thus exclude from the analysis those couples where the members of the couple have different levels of education.
} 
some older youngsters stay at home to take advantage of their parents' inputs of housework time.

\section{Conclusions}

This paper examines the relationship between parents' time devoted to housework and the time devoted to housework by their children. Using data from the Multinational Time Use Study for Germany and Spain, we find positive correlations between parents' and children's housework time, indicating that the more time parents devote to housework, the more time their children will devote to housework. However, we find cross-country and gender differences in these relationships, and while in Germany both fathers' and mothers' housework is positively related to the time devoted to housework by the children, in Spain it is only fathers' time in housework that is positively related to children's housework time. We offer an interpretation of the channels through which cross-country differences can be explained, although we are not able to determine which channel is more influential. We leave this issue for future research.

We also find that the results are different depending on the labor force status and educational level of the couple, which may indicate that parents transmit gender roles through education, with highly educated parents being able to transmit their gender roles more easily. Furthermore, if we restrict the analysis to youngsters aged 11 to 18 , our results for Spain indicate that some older youngsters may stay at home to take advantage of their parents' inputs of housework time. We leave the analysis of these differences for future research.

The presence of a gender gap in housework is important for wellbeing, as housework has been reported to be among the less enjoyable daily activities. Our results may be helpful for targeting public policies towards greater gender equality, which is very important in our context as there are robust and persistent gender gaps in housework time favoring men in developed countries. The reported correlations in housework time between parents should be taken into account when implementing public policies towards gender equality, as they create persistent effects (for or against gender equality) over time. In this sense, certain interventions over the housework time of the parents may modify the gender distribution of household labor towards a greater gender equality, which will contribute to a more egalitarian gender distribution of housework in the next generation, who will themselves become parents one day and may potentially transmit these norms to a third generation. Thus, given the multiplier 
effect of public policies, efforts to increase the gender equality of housework time are needed. At this time, the European Commission is developing a strategic and comprehensive vision to guide action at EU level post-2015, after implementing the "Strategy for equality between men and women 2010-201-", which includes a focus on gender equality in leisure time (Gimenez-Nadal, 2015). Our results here may serve as a benchmark for orienting this policy debate.

One limitation of our analysis is that our data is a cross-section of individuals, and thus reverse causality prevents us from making claims of causality. This is particularly important in our context, as it could be that preferences for housework differ by gender, or by household, or that productivities are different for different types of individuals. Also, reverse causality issues may be biasing our results, as some children may stay at home in order to take advantage of their parents' inputs, which may be biasing our results downward. Unfortunately, there are no panels of time-use surveys currently available, and some authors (Gimenez-Nadal, Molina and Zu, 2014) have proposed the use of datasets with a panel-data structure and information on weekly housework time.

\section{REFERENCES}

Aguiar, M., and E. Hurst (2007). "Measuring trends in leisure: the allocation of time over five decades," Quarterly Journal of Economics 122: 969-1006.

Akerlof G.A., and R.E. Kranton (2000). "Economics and Identity," Quarterly Journal of Economics 115: 715-753.

Aliaga, C. (2006). "How is the Time of Women and Men Distributed in Europe," Luxembourg: Eurostat.

Álvarez, B., and D. Miles (2012). "Exploring the relationship between children's and parents' housework time in Spain," Review of Economics of the Household 10: 299-318

Amato, P., and D. Deboer (2001). "The Transmission of Marital Instability Across Generations: Relationship Skills or Commitment to Marriage?" Journal of Marriage and Family 63: 1038-1051.

Angelini, V., and A. Laferrère (2013). "Parental altruism and nest leaving in Europe: evidence from a retrospective survey," Review of Economics of the Household 11: 393-420

Angelini, V., A. Laferrère and G. Pasini (2011). "Nest leaving in Europe," in The Individual and the Welfare State, eds. Börsch-Supan, Brandt, Hank and Schröder, pp 67-80. Springer

Anger, S. (2012). "Intergenerational transmission of cognitive and noncognitive skills," In From parents to children. The intergenerational transmission of advantage, Ermisch, Jäntti and Smeeding (eds.), New York: Russell Sage Foundation, pp. 393-421

Anger, S., and G. Heineck (2010). "Do Smart Parents Raise Smart Children? The Intergenerational Transmission of Cognitive Abilities," Journal of Population Economics 
23: $1105-1132$.

Apps, P., and R. Rees (2005). "Gender, Time Use, and Public Policy over the Life Cycle," Oxford Review of Economic Policy 21: 439-461.

Becker, G.S. (1991). A Treatise on the Family. Enlarged Edition. Cambridge, MA: Harvard University Press.

Becker, S., S. Bentolila, A. Fernandez and A. Ichino (2010). "Youth Emancipation and Perceived Job Insecurity of Parents and Children," Journal of Population Economics 23: 1047-1071.

Bianchi, S., M. Milkie, L. Sayer and J.P. Robinson (2000). "Is anyone doing the housework? Trends in the gender division of household labor," Social Forces 79: 191-228.

Billari F.C., Philipov D. and Baizán P. (2001) "Leaving home in Europe: the experience of cohorts born around 1960". Working Paper 2001-14. Max Planck Institute for Demographic Research

Billari, F.C., and G. Tabellini (2011). "Italians are Late: Does It Matter?" in Demography and the Economy, Ed. Shoven. Chicago: University of Chicago Press.

Bisin, A., and T. Verdier (2011). "The economics of cultural transmission and the dynamic of preferences," Journal of Economic Theory 97: 298-319.

Black, S.E., and P.J. Devereux (2011). "Recent developments in intergenerational mobility," In Handbook of Labor Economics, Vol 4b, Card and Ashenfelter (eds.), Elsevier, pp. 14871541.

Blossfeld, H.P., and A. Timm (2003). Who marries whom? Educational systems as marriage markets in modern societies. Dordrecht: Kluwer Academic Publishers.

Boeri, T., and J. Van Ours (2008). The Economics of Imperfect Labor Markets. Princeton University Press.

Bonke, J. (2005). "Paid work and unpaid work: Diary information versus questionnaire information," Social Indicators Research 70: 349-368.

Booth, A., and H. Kee (2009). "Intergenerational Transmission of Fertility Patterns," Oxford Bulletin of Economics and Statistics 71: 183-208.

Bulte, E.H., and R.D. Horan (2011). "Intergenerational transmission of preferences," Economics Letters 112: 85-87.

Burda, M., D. Hamermesh and P. Weil (2008). "The Distribution of Total Work in the US and EU," in Working Hours and Job Sharing in the EU and USA: Are Americans Crazy? Are Europeans Lazy? Boeri, Burda and Kramarz (eds.), Oxford Univ. Press.

Burda, M., D. Hamermesh and P. Weil (2013)." Total work and gender: facts and possible explanations," Journal of Population Economics 26: 239-261.

Cardoso, A.R., E. Fontainha and C. Monfardini (2010). "Children's and parents' time use: empirical evidence on investment in human capital in France, Germany and Italy," Review of Economics of the Household 8: 479-504.

Carlsson, F., E. Lampi, W. Li and P. Martinsson (2014). "Subjective well-being among preadolescents and their parents: Evidence of intergenerational transmission of well-being from urban China," Journal of Socio-Economics, http://dx.doi.org/10.1016/j.socec.2013.10.003. 
Carroll, C.D., B.K. Rhee and C. Rhee (1994). "Are there cultural effects on saving? Some cross-sectional evidence,” Quarterly Journal of Economics 109: 685-699.

Clair, A. (2012). "The relationship between parent's subjective well-being and the life satisfaction of their children in Britain," Child Indicators Research 5: 631-650.

Cohen, P.N. (1998). "Replacing Housework in the Service Economy," Gender and Society 12: 219-232.

Corak, M. (2013). "Income inequality, equality of opportunity, and intergenerational mobility," Journal of Economic Perspectives 27: 79-102.

Cunningham, M. (2001). "Parental influences on the gendered division of housework," American Sociological Review 66: 184-203.

Del Boca, D. (2002). "Low fertility and labour force participation of Italian women: evidence and interpretations," OECD Labour Market and Social Policy Occasional Papers No. 61, OECD.

Doepke, M., and F. Zilibotti (2012). "Intergenerational Transmission of Risk Preferences, Entrepreneurship, and Growth," 2012 Meeting Papers 246, Society for Economic Dynamics.

Doepke, M., and F. Zilibotti (2014). "Parenting with Style: Altruism and Paternalism in Intergenerational Preference Transmission," NBER Working Papers 20214, National Bureau of Economic Research

Dohmen, T., A. Falk, D. Huffman and U. Sunde (2012). "The intergenerational transmission of risk and trust attitudes," Review of Economic Studies 79: 645-677.

EUROSTAT (2013). Statistics, Population and Social Conditions.

Farré, L., and F. Vella (2013). "The Intergenerational Transmission of Gender Role Attitudes and its Implications for Female Labor Force Participation,” Economica 80: 219-247.

Fernández, R., and A. Fogli (2006). "Fertility: The role of culture and family experience," Journal of the European Economic Association 4: 522-561.

Fernández, R., and A. Fogli (2009). "Culture: An empirical investigation of beliefs, work, and fertility," American Economic Journal: Macroeconomics 1: 146-177.

Fernández, R., A. Fogli and C. Olivetti (2004). "Mothers and Sons: Preference Formation and Female Labor Force Dynamics," The Quarterly Journal of Economics 119: 1249-1299.

Fisher K, J. Gershuny and A. Gauthier (2011). "Multinational Time Use Study: User's Guide and Documentation," http://www.timeuse.org/files/cckpub/858/mtus-user-guide-r4.pdf.

Fisher, K., and J.P. Robinson (2011). "Daily Life in 23 Countries," Social Indicators Research 101: 295-304.

Gálvez-Muñoz L， P. Rodríguez-Modroño and M. Domínguez-Serrano (2011). "Work and Time Use By Gender: A New Clustering of European Welfare Systems," Feminist Economics 17: 125-157.

Gauthier, A.H., T.M. Smeeding, and F.F. Furstenberg (2004). "Are parents investing less time in children? Trends in selected industrialized countries," Population and Development Review 30: 647-671.

Gershuny, J. (2000). Changing times, work and leisure in post industrial society. Oxford: Oxford University Press. 
Gershuny, J.I. (2009). "Veblen in Reverse: Evidence from the Multinational Time-Use Archive," Social Indicators Research 93: 37-45.

Gershuny, J., and O. Sullivan (2003). "Time use, gender, and public policy regimes," Social Politics: International Studies in Gender, State and Society 10: 205-228.

Gimenez-Nadal, J.I. (2015). "Gender inequality in leisure time" in Visions on Gender Equality, Eds. Bettio and Sansonetti, Report prepared by ENEGE Network for the European Commission, DG Justice Unit D2.

Giménez-Nadal, J.I., and J.A. Molina (2013). "Parents' education as determinant of educational childcare time," Journal of Population Economics 26: 719-749.

Gimenez-Nadal, J.I., and J.A. Molina (2014). "Regional unemployment, gender and time allocation of the unemployed," Review of Economics of the Household 12: 105-127.

Gimenez-Nadal, J.I, and J. A. Molina (2015). "Voluntary Work and Daily Happiness in the US," Economic Inquiry, 53: 1735-1750.

Gimenez-Nadal, J.I, J.A. Molina and A. Sevilla (2012). "Social Norms, Partnerships and Children," Review of Economics of the Household, 10: 215-236.

Gimenez-Nadal, J.I, J.A. Molina and Y. Zhu (2014). "Intergenerational mobility of housework time in the United Kingdom," IZA Discussion Paper $N^{o} 8674$.

Gimenez-Nadal, J.I., and A. Sevilla (2011). "The Time-Crunch Paradox," Social Indicators Research 102: 181-196.

Giménez-Nadal, J.I. and A. Sevilla (2012). "Trends in time allocation: A cross-country analysis," European Economic Review 56: 1338-1359.

Giuliano, P. (2007). "Living Arrangements in Western Europe: Does Cultural Origin Matter?" Journal of the European Economic Association 5: 927-952.

Giuliano, P., and A. Alesina (2010). "The Power of the Family" (with Alberto Alesina), Journal of Economic Growth 15 (2): 93-125

Gronhof, A., and J. Thogersen (2009). "Like father, like son? Intergenerational transmission of values, attitudes, and behaviours in the environmental domain," Journal of Environmental Psychology 29: 414-421.

Grossbard, S., J.I. Gimenez-Nadal and J.A. Molina (2014). "Racial Intermarriage and Household Production," Review of Behavioral Economics 1: 295-347.

Guryan, J., E. Hurst, and M. Kearney (2008). "Parental education and parental time with children," Journal of Economic Perspectives 22: 23-46.

Hérault, N., and G. Kalb (2015). "Intergenerational correlation of labor market outcomes," Review of Economics of the Household, forthcoming.

Hersch, J., and L. Stratton (2002). "Housework and Wages," Journal of Human Resources 37: 217-229.

Holmlund, H., M. Lindahl and E. Plug (2011). "The causal effects of parent's education on children' schooling: a comparison of estimation methods," Journal of Economic Literature 49: 615-651.

Juster, T. and F. Stafford (1985). Time, Goods, and Well-Being. Ann Arbor, MI. Institute for Social Research.

Kahneman, D., and A.B. Krueger (2006). "Developments in the Measurement of Subjective 
Well-Being," Journal of Economic Perspectives 20: 3-24.

Kahneman, D., A.B. Krueger, D. Schkade, N. Schwarz and A. Stone (2004). "A Survey Method for Characterizing Daily Life Experience: The Day Reconstruction Method," Science 3: 1776-1780.

Klevmarken, N.A. (2005). "Estimates of a labour supply function using alternative measures of hours of work," European Economic Review 49: 55-73.

Krueger, A.B. (2007). "Are We Having More Fun Yet? Categorizing and Evaluating Changes in Time Allocation," Brookings Papers on Economic Activity 2: 193-217.

Lewis, S.K., and V.K. Oppenheimer (2000). "Educational assortative mating across marriage markets: non-Hispanic whites in the United States," Demography 37: 29-40.

Lucifora, C., and E. Cottini (2013). "Mental health and working conditions in Europe," Industrial and Labor Relations Review 66: 958-988.

Mare, R. (1991). "Five decades of educational assortative mating" American Sociological Review 56: 15-32.

Oppenheimer, V.K. (1988). "A theory of marriage timing: Assortative mating under varying degrees of uncertainty," American Journal of Sociology 94: 563-591.

Pencavel, J. (1998). "Assortative mating by schooling and the work behavior of wives and husbands," American Economic Review 88: 326-329.

Robinson, JP (1985). "The validity and reliability of diaries versus alternative time use measures," in Time, goods, and well-being, Juster and Stafford (eds). Ann Arbor, MI: The University of Michigan, pp 33-62.

Robinson, J.P., and G. Godbey (1997). Time for Life: The Surprising Ways Americans Use their Time. University Park, PA. Pennsylvania State University Press.

Sevilla, A. (2010). "Household división of labor and cross-country differences in household formation rates," Journal of Population Economics 23: 225-249.

Sevilla, A., J.I. Gimenez-Nadal and C. Fernandez (2010). "Gender Roles and the Division of Unpaid Work in Spanish Households," Feminist Economics 16: 137-184.

Sevilla, A., J.I. Gimenez-Nadal, and J.I. Gershuny (2012). "Leisure inequality in the United States: 1965-2003," Demography 49: 939-964

Solaz A., and F.C. Wolff (2015). "Intergenerational transmission of domestic work and gender roles," Annals of Economics and Statistics, forthcoming

Solon, G. (2002). "Cross-country differences in intergenerational earnings mobility," Journal of Economic Perspectives 16: 56-66.

Solon, G. (2004). "A model of intergenerational mobility variation over time and place," In Generational Income Mobility in north America and Europe, Corak (ed.). Cambridge University Press.

Stella, L. (2013). "Intergenerational transmission of human capital in Europe: evidence from SHARE," IZA Journal of European Labor Studies, 2-13.

Tsou, M.W., J.T. Liu and J.K. Hammitt (2012). "The intergenerational transmission of education: Evidence from Taiwanese adoptions," Economics Letters 115: 134-136.

Wilhelm, M.O., E. Brown, P.M. Rooney and R. Steinberg (2008). "The intergenerational transmission of generosity," Journal of Public Economics 92: 2146-2156. 
Winkelmann, R. (2005). "Subjective Well-Being and the Family: Results from an Ordered Probit Model with Multiple Random Effects," Empirical Economics 30: 749-761.

Wolfinger, N. (2000). "Beyond the Intergenerational Transmission of Divorce: Do People Replicate the Patterns of Marital Instability They Grew Up With?" Journal of Family Issues 21: 1061-1086.

Yee-Kan, M. (2008). "Measuring Housework Participation: The Gap Between "Stylised" Questionnaire Estimates and Diary-Based Estimates," Social Indicators Research 86: 381400 . 
Figure 1. Mean time devoted to non-market work, fathers and their children
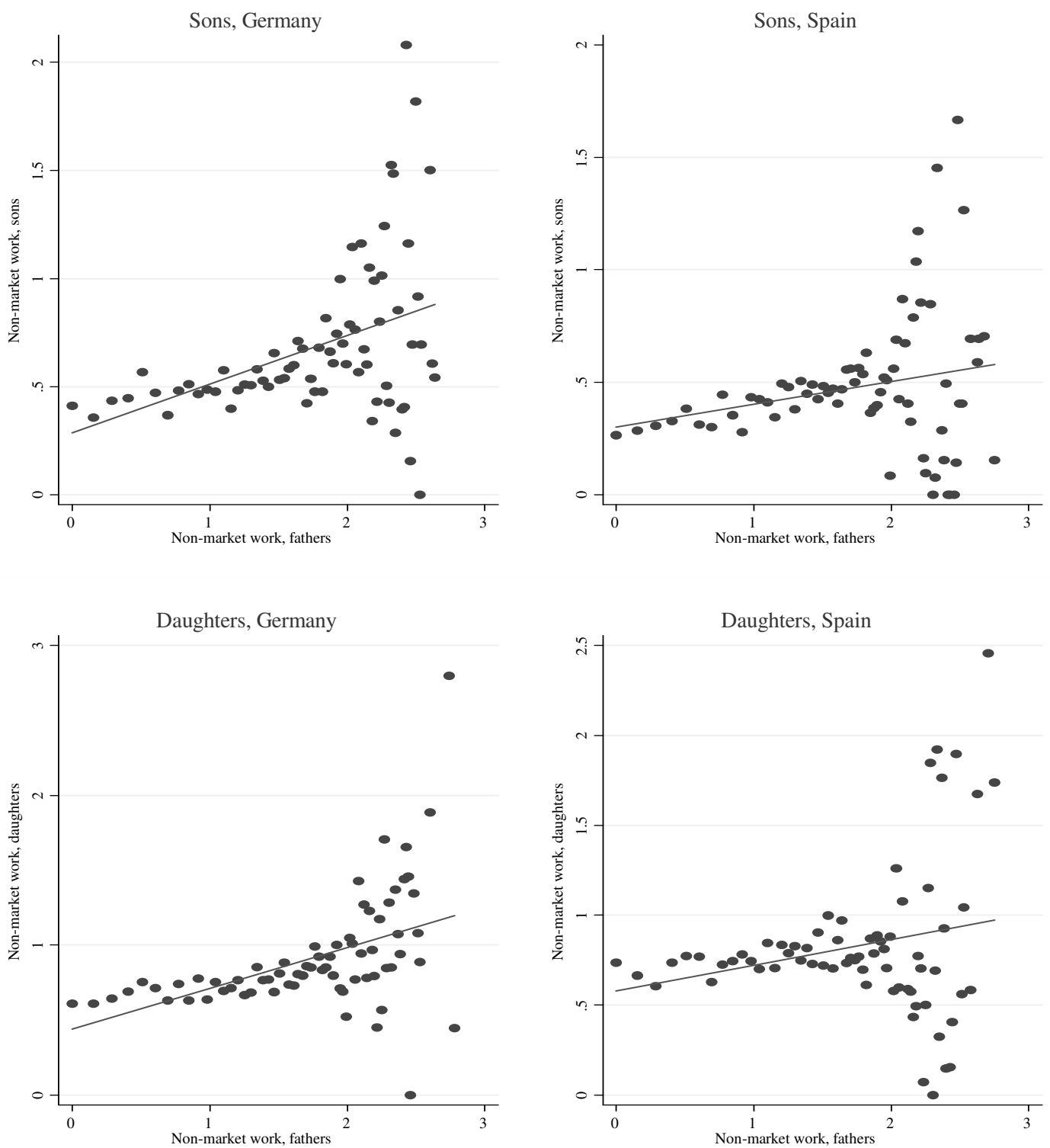

Note: Sample consists of individuals who are 10 years of age or older who are reported as being a child in the household, and living with two heterosexual parents. We include fathers of those children. Housework includes the total time devoted to the following activities: "cook, wash up", "housework", "odd jobs", "shopping" and "domestic travel", and is measured in (log) hours per day. 
Figure 2. Mean time devoted to non-market work, mothers and their children
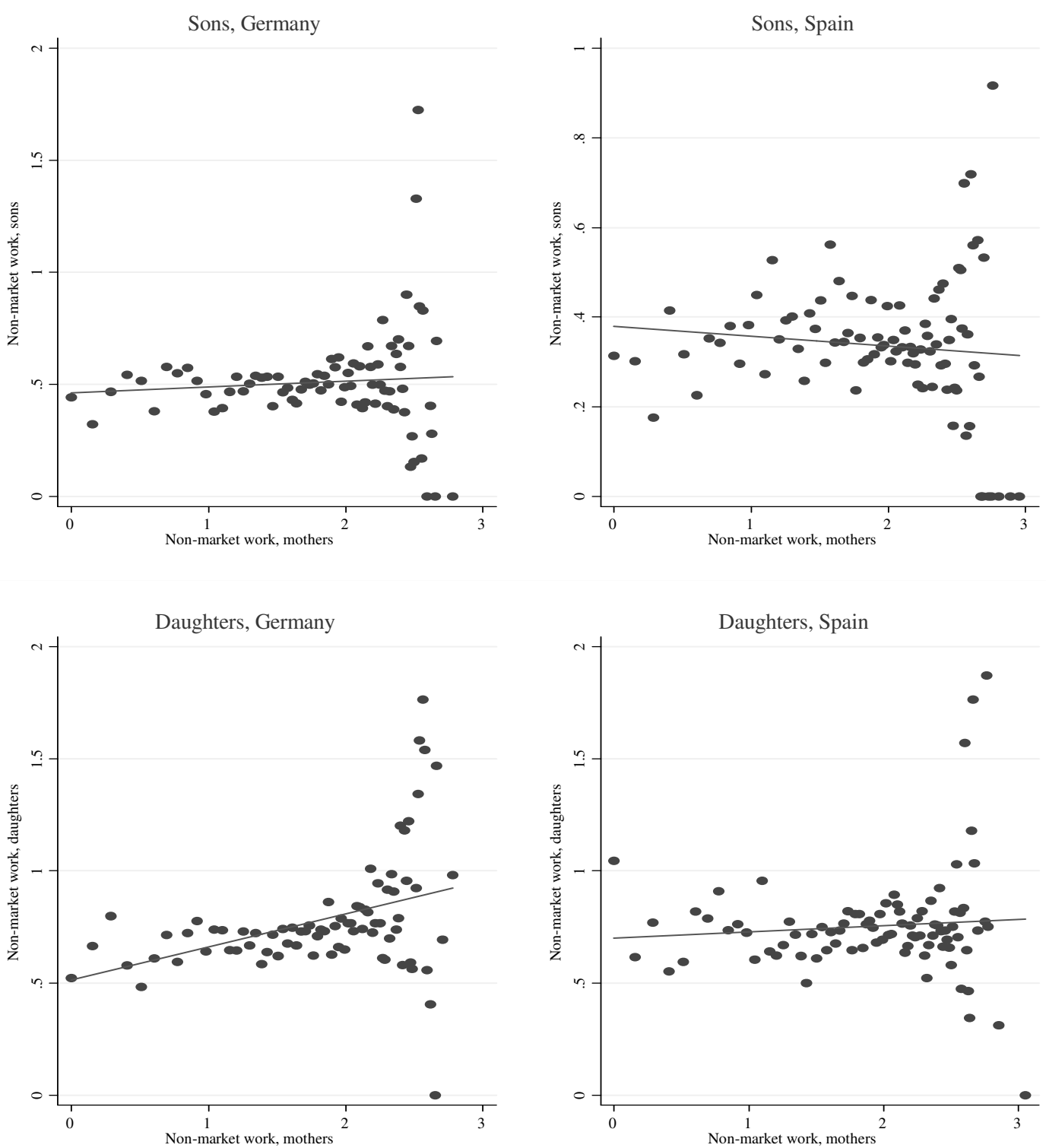

Note: Sample consists of individuals who are 10 years of age or older who are reported as being a child in the household, and living with two heterosexual parents. We include mothers of those children. Housework includes the total time devoted to the following activities: "cook, wash up", "housework", "odd jobs", "shopping" and "domestic travel", and is measured in $(\log )$ hours per day. 
Table 1. Sum stats of variables, by country

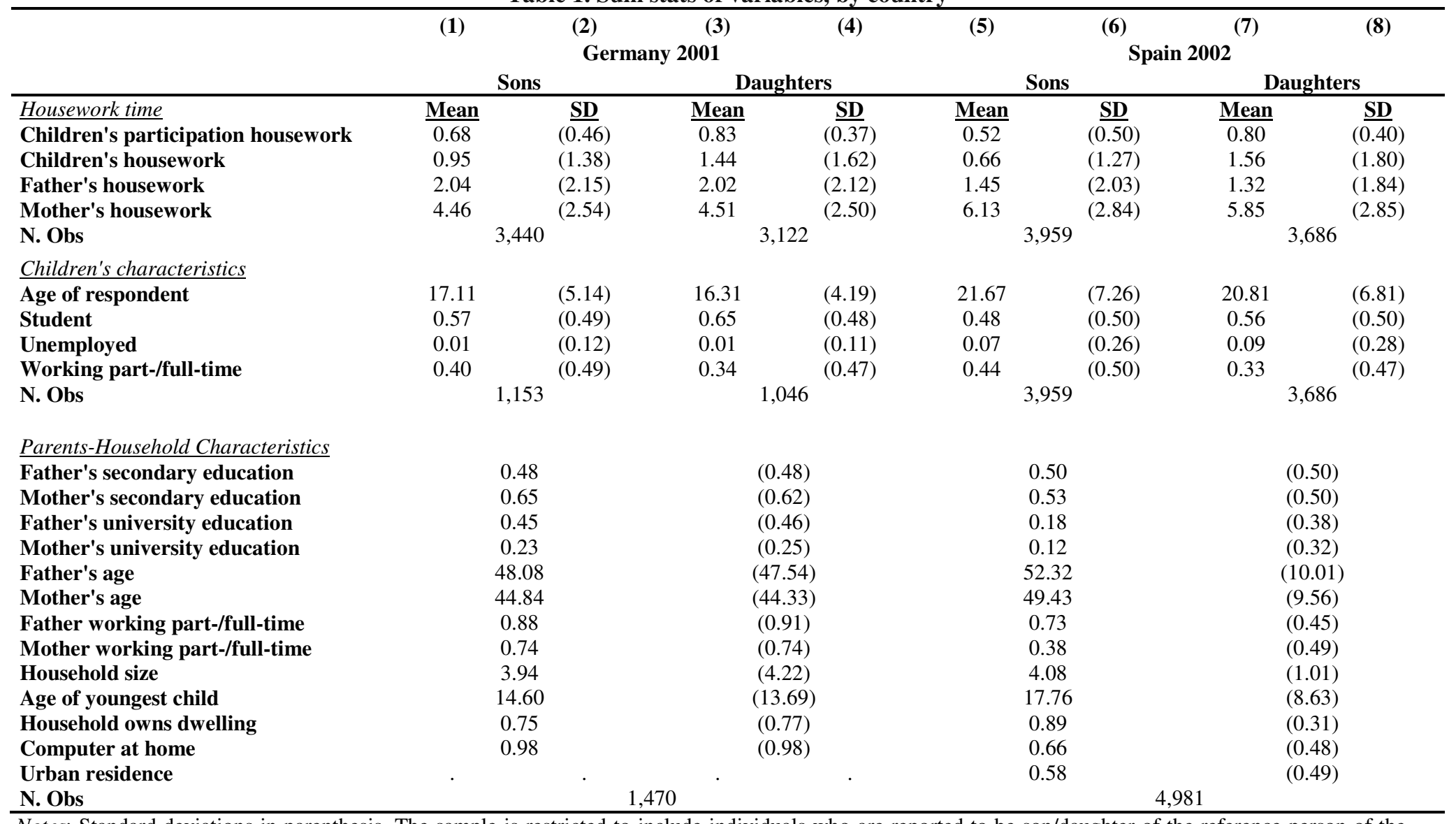

Notes: Standard deviations in parenthesis. The sample is restricted to include individuals who are reported to be son/daughter of the reference person of the household in the Multinational Time Use Study (MTUS) from Germany and Spain. Housework is measured in hours per day, and is defined as the sum of the time devoted to "cook, wash up", "housework", "odd jobs", "shopping" and "domestic travel." While sum stats for participation in and time in housework are obtained at the diary level, sum stats for demographic characteristics are obtained at the individual level. Given that in some households there may be two or more children, the number of parents does not correspond to the number of children in our sample. 
Table 2. Regression results for housework time of children, by country

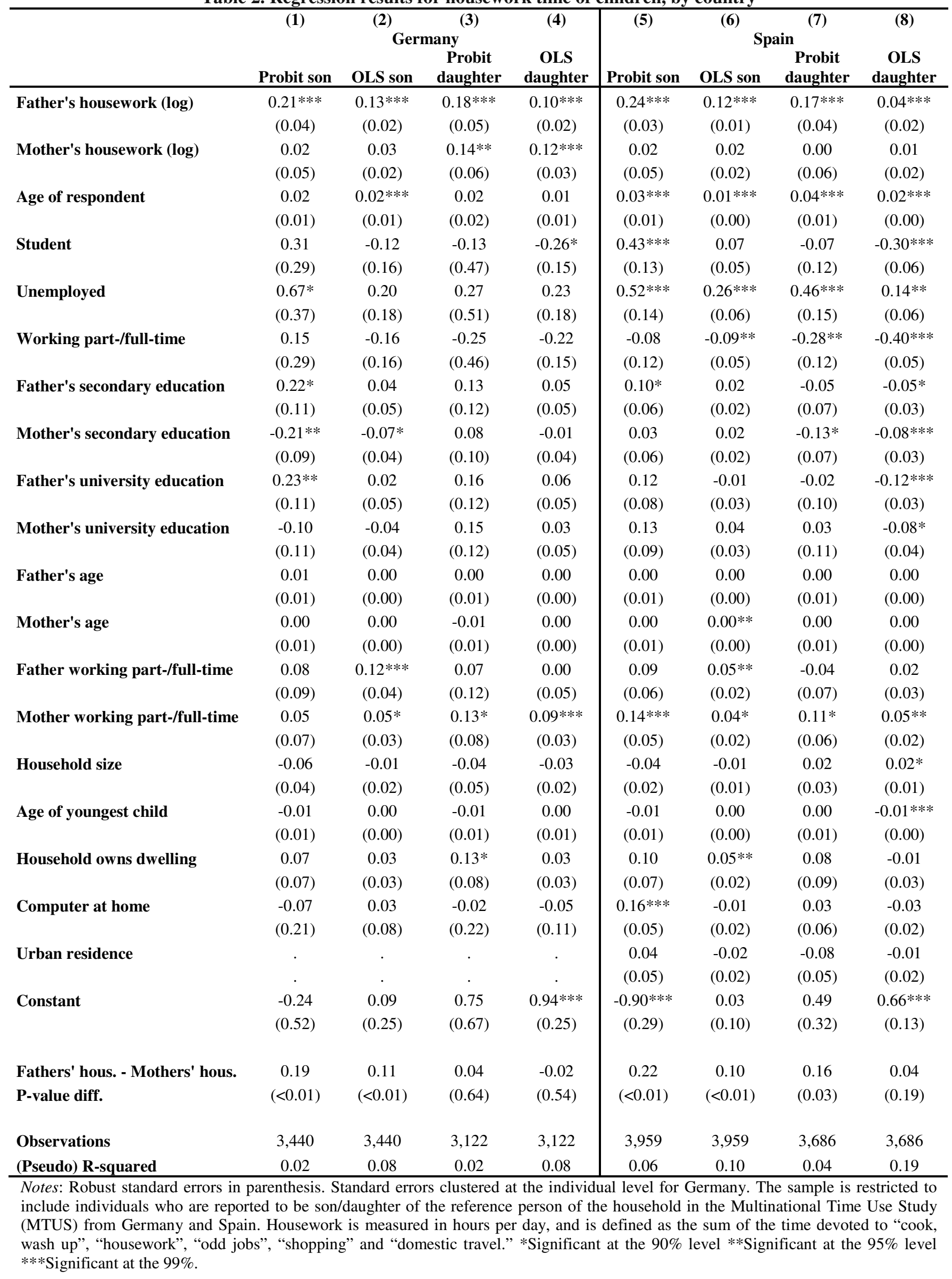


Table 3. FE Regressions for housework, Germany

\begin{tabular}{lcc}
\hline & \multicolumn{2}{c}{$(\mathbf{1})$} \\
& FE son & FE daughter \\
\hline Father's housework (log) & $0.09 * * *$ & $0.07 * * *$ \\
& $(0.02)$ & $(0.02)$ \\
Mother's housework (log) & $0.07 * * *$ & $0.15^{* * *}$ \\
& $(0.02)$ & $(0.03)$ \\
Constant & $0.48^{* * *}$ & $0.63 * * *$ \\
& $(0.04)$ & $(0.05)$ \\
Fathers' hous. - Mothers' hous. & 0.0184 & -0.0726 \\
P-value diff. & $(0.55)$ & $(0.03)$ \\
& & \\
Observations & 3,440 & 3,122 \\
Individuals & 1,226 & 1,095 \\
(Pseudo) R-squared & 0.06 & 0.08 \\
\hline
\end{tabular}

Notes: Robust standard errors in parenthesis. The sample is restricted to include individuals who are reported to be son/daughter of the reference person of the household in the Multinational Time Use Study (MTUS) from Germany. Housework is measured in hours per day, and is defined as the sum of the time devoted to "cook, wash up", "housework", "odd jobs", "shopping" and "domestic travel." *Significant at the $90 \%$ level **Significant at the $95 \%$ level ***Significant at the $99 \%$. 
Table 4. Regression results for housework, by country and demographic groups

\begin{tabular}{|c|c|c|c|c|c|c|c|c|}
\hline & Probit son & $\begin{array}{r}\text { (2) } \\
\text { Ger } \\
\text { OLS son } \\
\end{array}$ & $\begin{array}{l}\text { (3) } \\
\text { any } \\
\text { Probit } \\
\text { daughter }\end{array}$ & $\begin{array}{c}\text { (4) } \\
\text { OLS } \\
\text { daughter }\end{array}$ & Probit son & OLS son & $\begin{array}{l}\text { (7) } \\
\text { in Probit } \\
\text { daughter }\end{array}$ & $\begin{array}{c}\text { (8) } \\
\text { OLS } \\
\text { daughter }\end{array}$ \\
\hline & \multicolumn{8}{|c|}{ Panel A: male-earner households } \\
\hline Mother's housework (log) & $\begin{array}{l}0.17 * * \\
(0.07) \\
-0.11 \\
(0.10)\end{array}$ & $\begin{array}{c}0.10 * * * \\
(0.03) \\
0.00 \\
(0.03)\end{array}$ & $\begin{array}{c}0.21 * * \\
(0.10) \\
0.08 \\
(0.12)\end{array}$ & $\begin{array}{c}0.15 * * * \\
(0.05) \\
0.14 * * * \\
(0.05)\end{array}$ & $\begin{array}{c}0.22 * * * \\
(0.05) \\
-0.06 \\
(0.08)\end{array}$ & $\begin{array}{c}0.13 * * * \\
(0.02) \\
0.00 \\
(0.03)\end{array}$ & $\begin{array}{c}0.18 * * * \\
(0.06) \\
0.02 \\
(0.09)\end{array}$ & $\begin{array}{c}0.06 * * \\
(0.03) \\
0.03 \\
(0.03)\end{array}$ \\
\hline $\begin{array}{l}\text { Fathers' hous. - Mothers' hous. } \\
\text { P-value diff. }\end{array}$ & $\begin{array}{c}0.28 \\
(0.02)\end{array}$ & $\begin{array}{c}0.10 \\
(0.02)\end{array}$ & $\begin{array}{c}0.14 \\
(0.34)\end{array}$ & $\begin{array}{c}0.01 \\
(0.85)\end{array}$ & $\begin{array}{c}0.28 \\
(<0.01)\end{array}$ & $\begin{array}{c}0.12 \\
(<0.01)\end{array}$ & $\begin{array}{c}0.17 \\
(0.14)\end{array}$ & $\begin{array}{c}0.03 \\
(0.46)\end{array}$ \\
\hline $\begin{array}{l}\text { Observations } \\
\text { (Pseudo) R-squared }\end{array}$ & $\begin{array}{c}901 \\
0.04 \\
\end{array}$ & $\begin{array}{l}901 \\
0.10\end{array}$ & $\begin{array}{l}865 \\
0.05 \\
\end{array}$ & $\begin{array}{c}865 \\
0.10 \\
\end{array}$ & $\begin{array}{c}1,847 \\
0.06 \\
\end{array}$ & $\begin{array}{c}1,847 \\
0.11 \\
\end{array}$ & $\begin{array}{c}1,731 \\
0.04 \\
\end{array}$ & $\begin{array}{c}1,731 \\
0.18 \\
\end{array}$ \\
\hline & \multicolumn{8}{|c|}{ Panel B: two-earners households } \\
\hline Mother's housework (log) & $\begin{array}{c}0.24 * * * \\
(0.05) \\
0.08 \\
(0.06)\end{array}$ & $\begin{array}{c}0.14 * * * \\
(0.02) \\
0.05 * * \\
(0.02)\end{array}$ & $\begin{array}{c}0.15 * * * \\
(0.06) \\
0.21 * * * \\
(0.07)\end{array}$ & $\begin{array}{c}0.08 * * * \\
(0.02) \\
0.15^{* * * *} \\
(0.03)\end{array}$ & $\begin{array}{c}0.32 * * * \\
(0.06) \\
0.14 * \\
(0.07)\end{array}$ & $\begin{array}{c}0.13 * * * \\
(0.03) \\
0.07 * * * \\
(0.03)\end{array}$ & $\begin{array}{c}0.22 * * * \\
(0.08) \\
0.05 \\
(0.09)\end{array}$ & $\begin{array}{c}0.06 * * \\
(0.03) \\
0.01 \\
(0.03)\end{array}$ \\
\hline $\begin{array}{l}\text { Fathers' hous. - Mothers' hous. } \\
\text { P-value diff. }\end{array}$ & $\begin{array}{c}0.16 \\
(0.05)\end{array}$ & $\begin{array}{c}0.08 \\
(0.01)\end{array}$ & $\begin{array}{l}-0.06 \\
(0.57)\end{array}$ & $\begin{array}{l}-0.07 \\
(0.07)\end{array}$ & $\begin{array}{c}0.17 \\
(0.09)\end{array}$ & $\begin{array}{c}0.06 \\
(0.09)\end{array}$ & $\begin{array}{c}0.17 \\
(0.17)\end{array}$ & $\begin{array}{c}0.05 \\
(0.27)\end{array}$ \\
\hline $\begin{array}{l}\text { Observations } \\
\text { (Pseudo) R-squared }\end{array}$ & $\begin{array}{c}2,366 \\
0.03 \\
\end{array}$ & $\begin{array}{c}2,366 \\
0.09\end{array}$ & $\begin{array}{c}2,132 \\
0.03 \\
\end{array}$ & $\begin{array}{c}2,132 \\
0.09 \\
\end{array}$ & $\begin{array}{c}1,246 \\
0.08\end{array}$ & $\begin{array}{c}1,246 \\
0.11 \\
\end{array}$ & $\begin{array}{c}1,262 \\
0.05\end{array}$ & $\begin{array}{c}1,262 \\
0.14 \\
\end{array}$ \\
\hline & \multicolumn{8}{|c|}{ Panel C: Primary education households } \\
\hline $\begin{array}{l}\text { Father's housework (log) } \\
\text { Mother's housework (log) }\end{array}$ & $\begin{array}{c}0.22 * \\
(0.13) \\
0.05 \\
(0.15)\end{array}$ & $\begin{array}{l}0.17 * * \\
(0.07) \\
0.17 * \\
(0.10)\end{array}$ & $\begin{array}{l}0.22 \\
(0.21) \\
-0.03 \\
(0.27)\end{array}$ & $\begin{array}{c}0.11 \\
(0.08) \\
0.13 \\
(0.10)\end{array}$ & $\begin{array}{c}0.25 * * * \\
(0.06) \\
0.10 \\
(0.08)\end{array}$ & $\begin{array}{c}0.11 * * * \\
(0.03) \\
0.04 \\
(0.03)\end{array}$ & $\begin{array}{l}0.16^{*} \\
(0.08) \\
-0.12 \\
(0.11)\end{array}$ & $\begin{array}{c}0.01 \\
(0.03) \\
-0.08^{* *} \\
(0.04)\end{array}$ \\
\hline $\begin{array}{l}\text { Fathers' hous. - Mothers' hous. } \\
\text { P-value diff. }\end{array}$ & $\begin{array}{c}0.17 \\
(0.40)\end{array}$ & $\begin{array}{c}0.01 \\
(0.96)\end{array}$ & $\begin{array}{c}0.25 \\
(0.50)\end{array}$ & $\begin{array}{l}-0.03 \\
(0.85)\end{array}$ & $\begin{array}{c}0.15 \\
(0.13)\end{array}$ & $\begin{array}{c}0.07 \\
(0.06)\end{array}$ & $\begin{array}{c}0.28 \\
(0.04)\end{array}$ & $\begin{array}{c}0.09 \\
(0.10)\end{array}$ \\
\hline $\begin{array}{l}\text { Observations } \\
\text { (Pseudo) R-squared }\end{array}$ & $\begin{array}{l}198 \\
0.08 \\
\end{array}$ & $\begin{array}{l}200 \\
0.21 \\
\end{array}$ & $\begin{array}{l}182 \\
0.11 \\
\end{array}$ & $\begin{array}{c}182 \\
0.13 \\
\end{array}$ & $\begin{array}{c}1,284 \\
0.07 \\
\end{array}$ & $\begin{array}{c}1,284 \\
0.12 \\
\end{array}$ & $\begin{array}{c}1,112 \\
0.09 \\
\end{array}$ & $\begin{array}{c}1,114 \\
0.25 \\
\end{array}$ \\
\hline & \multicolumn{8}{|c|}{ Panel D: Secondary education households } \\
\hline $\begin{array}{l}\text { Father's housework (log) } \\
\text { Mother's housework (log) }\end{array}$ & $\begin{array}{c}0.27 * * * \\
(0.06) \\
-0.02 \\
(0.08)\end{array}$ & $\begin{array}{c}0.15^{* * *} \\
(0.02) \\
0.01 \\
(0.03)\end{array}$ & $\begin{array}{c}0.19 * * * \\
(0.07) \\
0.04 \\
(0.09)\end{array}$ & $\begin{array}{c}0.13 * * * \\
(0.03) \\
0.10 * * \\
(0.04)\end{array}$ & $\begin{array}{c}0.23 * * * \\
(0.05) \\
-0.02 \\
(0.07)\end{array}$ & $\begin{array}{c}0.11 * * * \\
(0.02) \\
0.01 \\
(0.03)\end{array}$ & $\begin{array}{l}0.12^{*} \\
(0.06) \\
-0.04 \\
(0.08)\end{array}$ & $\begin{array}{c}0.03 \\
(0.02) \\
0.02 \\
(0.03)\end{array}$ \\
\hline $\begin{array}{l}\text { Fathers' hous. - Mothers' hous. } \\
\text { P-value diff. }\end{array}$ & $\begin{array}{c}0.29 \\
(<0.01)\end{array}$ & $\begin{array}{c}0.14 \\
(<0.01)\end{array}$ & $\begin{array}{c}0.14 \\
(0.20)\end{array}$ & $\begin{array}{c}0.03 \\
(0.61)\end{array}$ & $\begin{array}{c}0.25 \\
(<0.01)\end{array}$ & $\begin{array}{c}0.10 \\
(<0.01)\end{array}$ & $\begin{array}{c}0.16 \\
(0.14)\end{array}$ & $\begin{array}{c}0.01 \\
(0.71)\end{array}$ \\
\hline $\begin{array}{l}\text { Observations } \\
\text { (Pseudo) R-squared }\end{array}$ & $\begin{array}{c}1,609 \\
0.04 \\
\end{array}$ & $\begin{array}{c}1,609 \\
0.11 \\
\end{array}$ & $\begin{array}{l}1,495 \\
0.03 \\
\end{array}$ & $\begin{array}{c}1,495 \\
0.09 \\
\end{array}$ & $\begin{array}{c}1,959 \\
0.05 \\
\end{array}$ & $\begin{array}{c}1,959 \\
0.10 \\
\end{array}$ & $\begin{array}{c}1,903 \\
0.04 \\
\end{array}$ & $\begin{array}{c}1,903 \\
0.14 \\
\end{array}$ \\
\hline & \multicolumn{8}{|c|}{ Panel E: University education households } \\
\hline Father's housework $(\log )$ & $\begin{array}{l}0.14 * * \\
(0.06)\end{array}$ & $\begin{array}{l}0.09^{* * *} \\
(0.02)\end{array}$ & $\begin{array}{l}0.16^{* *} \\
(0.08)\end{array}$ & $\begin{array}{c}0.07 * * * \\
(0.03)\end{array}$ & $\begin{array}{c}0.32 * * * \\
(0.09)\end{array}$ & $\begin{array}{c}0.17 * * * \\
(0.03)\end{array}$ & $\begin{array}{c}0.35 * * * \\
(0.11)\end{array}$ & $\begin{array}{l}0.12 * * * \\
(0.04)\end{array}$ \\
\hline Mother's housework (log) & $\begin{array}{c}0.08 \\
(0.07)\end{array}$ & $\begin{array}{c}0.03 \\
(0.03)\end{array}$ & $\begin{array}{c}0.23 * * \\
(0.09)\end{array}$ & $\begin{array}{c}0.14 * * * \\
(0.04)\end{array}$ & $\begin{array}{l}-0.03 \\
(0.11)\end{array}$ & $\begin{array}{c}0.00 \\
(0.04)\end{array}$ & $\begin{array}{c}0.10 \\
(0.14)\end{array}$ & $\begin{array}{l}0.07 * \\
(0.04)\end{array}$ \\
\hline $\begin{array}{l}\text { Fathers' hous. - Mothers' hous. } \\
\text { P-value diff. }\end{array}$ & $\begin{array}{c}0.06 \\
(0.55)\end{array}$ & $\begin{array}{c}0.07 \\
(0.06)\end{array}$ & $\begin{array}{l}-0.07 \\
(0.55)\end{array}$ & $\begin{array}{l}-0.07 \\
(0.14)\end{array}$ & $\begin{array}{c}0.35 \\
(0.02)\end{array}$ & $\begin{array}{c}0.17 \\
(<0.01)\end{array}$ & $\begin{array}{l}0.25 \\
(0.19)\end{array}$ & $\begin{array}{c}0.05 \\
(0.44)\end{array}$ \\
\hline $\begin{array}{l}\text { Observations } \\
\text { (Pseudo) R-squared }\end{array}$ & $\begin{array}{c}1,620 \\
0.03 \\
\end{array}$ & $\begin{array}{c}1,620 \\
0.09 \\
\end{array}$ & $\begin{array}{c}1,443 \\
0.04 \\
\end{array}$ & $\begin{array}{c}1,443 \\
0.09 \\
\end{array}$ & $\begin{array}{l}705 \\
0.07\end{array}$ & $\begin{array}{l}705 \\
0.11 \\
\end{array}$ & $\begin{array}{r}649 \\
0.07 \\
\end{array}$ & $\begin{array}{l}649 \\
0.16 \\
\end{array}$ \\
\hline
\end{tabular}

Notes: Robust standard errors in parenthesis. Standard errors clustered at the individual level for Germany. The sample is restricted to include individuals who are reported to be son/daughter of the reference person of the household in the Multinational Time Use Study (MTUS) from Germany and Spain. Housework is measured in hours per day, and is defined as the sum of the time devoted to "cook, wash up", "housework", "odd jobs", "shopping" and "domestic travel." *Significant at the $90 \%$ level **Significant at the 95\% level ***Significant at the $99 \%$. 
Table 5. Regression results for housework time of children 11-18, by country

\begin{tabular}{|c|c|c|c|c|c|c|c|c|}
\hline & (1) & $(2)$ & (3) & (4) & (5) & $(6)$ & (7) & (8) \\
\hline & \multicolumn{4}{|c|}{ Germany } & \multicolumn{4}{|c|}{ Spain } \\
\hline & $\begin{array}{c}\begin{array}{c}\text { Probit } \\
\text { son }\end{array} \\
\end{array}$ & OLS son & $\begin{array}{c}\begin{array}{c}\text { Probit } \\
\text { daughter }\end{array} \\
\end{array}$ & $\begin{array}{c}\text { OLS } \\
\text { daughter }\end{array}$ & $\begin{array}{c}\text { Probit } \\
\text { son }\end{array}$ & OLS son & $\begin{array}{c}\begin{array}{c}\text { Probit } \\
\text { daughter }\end{array} \\
\end{array}$ & $\begin{array}{c}\text { OLS } \\
\text { daughter }\end{array}$ \\
\hline Father's housework (log) & $\begin{array}{c}0.26 * * * \\
(0.05)\end{array}$ & $\begin{array}{c}0.14 * * * \\
(0.02)\end{array}$ & $\begin{array}{c}0.15 * * * \\
(0.06)\end{array}$ & $\begin{array}{c}0.09 * * * \\
(0.02)\end{array}$ & $\begin{array}{c}0.31 * * * \\
(0.06)\end{array}$ & $\begin{array}{c}0.16 * * * \\
(0.02)\end{array}$ & $\begin{array}{c}0.22 * * * \\
(0.06)\end{array}$ & $\begin{array}{c}0.06 * * \\
(0.02)\end{array}$ \\
\hline Mother's housework (log) & $\begin{array}{c}0.04 \\
(0.06)\end{array}$ & $\begin{array}{l}0.05^{*} \\
(0.02)\end{array}$ & $\begin{array}{c}0.15^{* *} \\
(0.07)\end{array}$ & $\begin{array}{c}0.16^{* * *} \\
(0.03)\end{array}$ & $\begin{array}{c}0.05 \\
(0.08)\end{array}$ & $\begin{array}{c}0.05^{* *} \\
(0.03)\end{array}$ & $\begin{array}{c}0.07 \\
(0.08)\end{array}$ & $\begin{array}{c}0.06 * * \\
(0.03)\end{array}$ \\
\hline Age of respondent & $\begin{array}{c}0.00 \\
(0.02)\end{array}$ & $\begin{array}{c}0.01 \\
(0.01)\end{array}$ & $\begin{array}{c}0.02 \\
(0.03)\end{array}$ & $\begin{array}{c}0.01 \\
(0.01)\end{array}$ & $\begin{array}{c}0.04 * * \\
(0.02)\end{array}$ & $\begin{array}{c}0.00 \\
(0.01)\end{array}$ & $\begin{array}{c}0.03 \\
(0.02)\end{array}$ & $\begin{array}{c}0.03 * * * \\
(0.01)\end{array}$ \\
\hline Student & $\begin{array}{c}0.13 \\
(0.62)\end{array}$ & $\begin{array}{l}-0.15 \\
(0.27)\end{array}$ & $\begin{array}{c}0.38 \\
(0.56)\end{array}$ & $\begin{array}{l}-0.25 \\
(0.28)\end{array}$ & $\begin{array}{c}0.65 * * * \\
(0.24)\end{array}$ & $\begin{array}{c}0.08 \\
(0.07)\end{array}$ & $\begin{array}{l}-0.24 \\
(0.21)\end{array}$ & $\begin{array}{c}-0.38 * * * \\
(0.10)\end{array}$ \\
\hline Unemployed & $\begin{array}{c}0.18 \\
(0.62)\end{array}$ & $\begin{array}{l}-0.07 \\
(0.27)\end{array}$ & $\begin{array}{l}-0.15 \\
(0.29)\end{array}$ & $\begin{array}{l}-0.15 \\
(0.29)\end{array}$ & $\begin{array}{c}0.49 \\
(0.31)\end{array}$ & $\begin{array}{c}0.05 \\
(0.10)\end{array}$ & $\begin{array}{l}-0.19 \\
(0.33)\end{array}$ & $\begin{array}{l}-0.07 \\
(0.17)\end{array}$ \\
\hline Working part-/full-time & $\begin{array}{c}0.01 \\
(0.62)\end{array}$ & $\begin{array}{l}-0.18 \\
(0.27)\end{array}$ & $\begin{array}{c}0.28 \\
(0.56)\end{array}$ & $\begin{array}{l}-0.21 \\
(0.28)\end{array}$ & $\begin{array}{c}0.06 \\
(0.25)\end{array}$ & $\begin{array}{l}-0.07 \\
(0.07)\end{array}$ & $\begin{array}{l}-0.23 \\
(0.23)\end{array}$ & $\begin{array}{c}-0.33 * * * \\
(0.12)\end{array}$ \\
\hline Father's secondary education & $\begin{array}{c}0.15 \\
(0.15)\end{array}$ & $\begin{array}{l}-0.02 \\
(0.07)\end{array}$ & $\begin{array}{l}-0.17 \\
(0.15)\end{array}$ & $\begin{array}{l}-0.08 \\
(0.06)\end{array}$ & $\begin{array}{c}0.14 \\
(0.10)\end{array}$ & $\begin{array}{c}0.01 \\
(0.03)\end{array}$ & $\begin{array}{l}-0.05 \\
(0.11)\end{array}$ & $\begin{array}{c}-0.07 * \\
(0.04)\end{array}$ \\
\hline Mother's secondary education & $\begin{array}{l}-0.21 \\
(0.13)\end{array}$ & $\begin{array}{l}-0.06 \\
(0.05)\end{array}$ & $\begin{array}{c}0.12 \\
(0.13)\end{array}$ & $\begin{array}{l}-0.02 \\
(0.05)\end{array}$ & $\begin{array}{c}0.03 \\
(0.10)\end{array}$ & $\begin{array}{c}0.04 \\
(0.03)\end{array}$ & $\begin{array}{l}-0.08 \\
(0.11)\end{array}$ & $\begin{array}{c}-0.09 * * \\
(0.04)\end{array}$ \\
\hline Father's university education & $\begin{array}{c}0.07 \\
(0.15)\end{array}$ & $\begin{array}{l}-0.06 \\
(0.07)\end{array}$ & $\begin{array}{l}-0.11 \\
(0.15)\end{array}$ & $\begin{array}{l}-0.07 \\
(0.06)\end{array}$ & $\begin{array}{c}0.18 \\
(0.12)\end{array}$ & $\begin{array}{c}0.00 \\
(0.04)\end{array}$ & $\begin{array}{l}-0.09 \\
(0.14)\end{array}$ & $\begin{array}{c}-0.11 * * \\
(0.05)\end{array}$ \\
\hline Mother's university education & $\begin{array}{l}-0.06 \\
(0.15)\end{array}$ & $\begin{array}{l}-0.02 \\
(0.05)\end{array}$ & $\begin{array}{c}0.13 \\
(0.14)\end{array}$ & $\begin{array}{c}0.02 \\
(0.06)\end{array}$ & $\begin{array}{c}0.05 \\
(0.13)\end{array}$ & $\begin{array}{c}0.04 \\
(0.05)\end{array}$ & $\begin{array}{c}0.31 \text { ** } \\
(0.15)\end{array}$ & $\begin{array}{l}-0.05 \\
(0.05)\end{array}$ \\
\hline Father's age & $\begin{array}{l}0.02 * \\
(0.01)\end{array}$ & $\begin{array}{c}0.00 \\
(0.00)\end{array}$ & $\begin{array}{c}0.01 \\
(0.01)\end{array}$ & $\begin{array}{c}0.00 \\
(0.00)\end{array}$ & $\begin{array}{c}0.00 \\
(0.01)\end{array}$ & $\begin{array}{c}0.00 \\
(0.00)\end{array}$ & $\begin{array}{l}-0.01 \\
(0.01)\end{array}$ & $\begin{array}{c}0.00 \\
(0.00)\end{array}$ \\
\hline Mother's age & $\begin{array}{l}-0.01 \\
(0.01)\end{array}$ & $\begin{array}{c}0.00 \\
(0.00)\end{array}$ & $\begin{array}{c}-0.02 * \\
(0.01)\end{array}$ & $\begin{array}{l}-0.01 * \\
(0.01)\end{array}$ & $\begin{array}{l}-0.01 \\
(0.01)\end{array}$ & $\begin{array}{c}0.00 \\
(0.00)\end{array}$ & $\begin{array}{c}0.00 \\
(0.01)\end{array}$ & $\begin{array}{c}0.00 \\
(0.00)\end{array}$ \\
\hline Father working part-/full-time & $\begin{array}{l}0.21 * \\
(0.13)\end{array}$ & $\begin{array}{c}0.12 * * \\
(0.05)\end{array}$ & $\begin{array}{c}0.04 \\
(0.15)\end{array}$ & $\begin{array}{c}0.02 \\
(0.06)\end{array}$ & $\begin{array}{l}0.23 * \\
(0.12)\end{array}$ & $\begin{array}{c}0.06 \\
(0.04)\end{array}$ & $\begin{array}{l}-0.13 \\
(0.13)\end{array}$ & $\begin{array}{l}-0.04 \\
(0.05)\end{array}$ \\
\hline Mother working part-/full-time & $\begin{array}{l}-0.05 \\
(0.09)\end{array}$ & $\begin{array}{c}0.03 \\
(0.03)\end{array}$ & $\begin{array}{l}0.15 * \\
(0.09)\end{array}$ & $\begin{array}{c}0.08 * * \\
(0.03)\end{array}$ & $\begin{array}{c}0.21 * * * \\
(0.08)\end{array}$ & $\begin{array}{c}0.04 \\
(0.03)\end{array}$ & $\begin{array}{c}0.09 \\
(0.09)\end{array}$ & $\begin{array}{c}0.08 * * \\
(0.03)\end{array}$ \\
\hline Household size & $\begin{array}{l}-0.05 \\
(0.04)\end{array}$ & $\begin{array}{c}0.00 \\
(0.02)\end{array}$ & $\begin{array}{c}0.01 \\
(0.06)\end{array}$ & $\begin{array}{c}0.00 \\
(0.02)\end{array}$ & $\begin{array}{c}0.00 \\
(0.04)\end{array}$ & $\begin{array}{c}0.01 \\
(0.01)\end{array}$ & $\begin{array}{c}0.11 * * * \\
(0.04)\end{array}$ & $\begin{array}{c}0.05 * * * \\
(0.02)\end{array}$ \\
\hline Age of youngest child & $\begin{array}{l}-0.01 \\
(0.02)\end{array}$ & $\begin{array}{l}-0.01 \\
(0.01)\end{array}$ & $\begin{array}{l}-0.01 \\
(0.02)\end{array}$ & $\begin{array}{c}0.01 \\
(0.01)\end{array}$ & $\begin{array}{l}-0.01 \\
(0.01)\end{array}$ & $\begin{array}{c}0.00 \\
(0.00)\end{array}$ & $\begin{array}{c}0.01 \\
(0.01)\end{array}$ & $\begin{array}{c}0.00 \\
(0.00)\end{array}$ \\
\hline Household owns dwelling & $\begin{array}{c}0.07 \\
(0.08)\end{array}$ & $\begin{array}{c}0.02 \\
(0.03)\end{array}$ & $\begin{array}{c}0.02 \\
(0.09)\end{array}$ & $\begin{array}{l}-0.02 \\
(0.04)\end{array}$ & $\begin{array}{c}0.07 \\
(0.10)\end{array}$ & $\begin{array}{c}0.07 * * \\
(0.03)\end{array}$ & $\begin{array}{c}0.06 \\
(0.11)\end{array}$ & $\begin{array}{c}0.00 \\
(0.04)\end{array}$ \\
\hline Computer at home & $\begin{array}{l}-0.15 \\
(0.32)\end{array}$ & $\begin{array}{c}0.00 \\
(0.11)\end{array}$ & $\begin{array}{l}-0.05 \\
(0.28)\end{array}$ & $\begin{array}{l}-0.08 \\
(0.12)\end{array}$ & $\begin{array}{c}0.07 \\
(0.09)\end{array}$ & $\begin{array}{l}-0.01 \\
(0.03)\end{array}$ & $\begin{array}{c}0.00 \\
(0.09)\end{array}$ & $\begin{array}{l}-0.05 \\
(0.03)\end{array}$ \\
\hline Urban residence & . & . & . & . & $\begin{array}{c}0.06 \\
(0.07)\end{array}$ & $\begin{array}{l}-0.01 \\
(0.02)\end{array}$ & $\begin{array}{c}-0.15^{* *} \\
(0.08)\end{array}$ & $\begin{array}{l}-0.02 \\
(0.03)\end{array}$ \\
\hline Constant & $\begin{array}{c}0.26 \\
(0.87)\end{array}$ & $\begin{array}{c}0.33 \\
(0.36)\end{array}$ & $\begin{array}{c}0.53 \\
(0.84)\end{array}$ & $\begin{array}{c}1.10^{* * *} \\
(0.37)\end{array}$ & $\begin{array}{c}-1.09 * * \\
(0.48)\end{array}$ & $\begin{array}{c}0.00 \\
(0.16)\end{array}$ & $\begin{array}{c}0.56 \\
(0.50)\end{array}$ & $\begin{array}{c}0.44 * * \\
(0.20)\end{array}$ \\
\hline $\begin{array}{l}\text { Fathers' hous. - Mothers' hous. } \\
\text { P-value diff. }\end{array}$ & $\begin{array}{l}0.223 \\
(0.01)\end{array}$ & $\begin{array}{r}0.0923 \\
(0.00)\end{array}$ & $\begin{array}{c}0.00314 \\
(0.97)\end{array}$ & $\begin{array}{c}-0.0669 \\
(0.06)\end{array}$ & $\begin{array}{l}0.259 \\
(0.01)\end{array}$ & $\begin{array}{l}0.102 \\
(0.00)\end{array}$ & $\begin{array}{c}0.15 \\
(0.16)\end{array}$ & $\begin{array}{c}-0.00407 \\
(0.92)\end{array}$ \\
\hline Observations & 2,236 & 2,236 & 2,244 & 2,247 & 1,530 & 1,530 & 1,546 & 1,546 \\
\hline (Pseudo) R-squared & 0.03 & 0.08 & 0.02 & 0.08 & 0.05 & 0.10 & 0.04 & 0.12 \\
\hline
\end{tabular}

Notes: Robust standard errors in parenthesis. Standard errors clustered at the individual level for Germany. The sample is restricted to include individuals who are reported to be son/daughter of the reference person of the household in the Multinational Time Use Study (MTUS) from Germany and Spain. Housework is measured in hours per day, and is defined as the sum of the time devoted to "cook, wash up", "housework", "odd jobs", "shopping" and "domestic travel." *Significant at the 90\% level **Significant at the 95\% level $* * *$ Significant at the $99 \%$. 


\section{APPENDIX A: Robustness tests}

Table A1. Tobit results for housework time of children, by country

\begin{tabular}{|c|c|c|c|c|}
\hline & \multirow{2}{*}{\multicolumn{2}{|c|}{$(1) \quad(2)$}} & \multirow{2}{*}{\multicolumn{2}{|c|}{ (3) Spain 2002}} \\
\hline & & & & \\
\hline & & Tobit & & Tobit \\
\hline & Tobit son & daughter & Tobit son & daughter \\
\hline \multirow[t]{2}{*}{ Father's housework $(\log )$} & $0.18^{* * *}$ & $0.12 * * *$ & $0.20 * * *$ & $0.06 * * *$ \\
\hline & $(0.02)$ & $(0.02)$ & $(0.02)$ & $(0.02)$ \\
\hline \multirow[t]{2}{*}{ Mother's housework (log) } & 0.03 & $0.14 * * *$ & 0.02 & 0.01 \\
\hline & $(0.03)$ & $(0.03)$ & $(0.03)$ & $(0.03)$ \\
\hline \multirow[t]{2}{*}{ Age of respondent } & $0.02 * * *$ & 0.01 & $0.02 * * *$ & $0.03 * * *$ \\
\hline & $(0.01)$ & $(0.01)$ & $(0.00)$ & $(0.00)$ \\
\hline \multirow[t]{2}{*}{ Student } & -0.09 & -0.28 & $0.20 * *$ & $-0.31 * * *$ \\
\hline & $(0.21)$ & $(0.17)$ & $(0.09)$ & $(0.06)$ \\
\hline \multirow[t]{2}{*}{ Unemployed } & 0.28 & 0.25 & $0.43 * * *$ & $0.17 * *$ \\
\hline & $(0.23)$ & $(0.20)$ & $(0.10)$ & $(0.07)$ \\
\hline \multirow[t]{2}{*}{ Working part-/full-time } & -0.16 & -0.25 & $-0.14 *$ & $-0.43 * * *$ \\
\hline & $(0.21)$ & $(0.17)$ & $(0.08)$ & $(0.06)$ \\
\hline \multirow[t]{2}{*}{ Father's secondary education } & 0.07 & 0.06 & 0.05 & -0.05 \\
\hline & $(0.07)$ & $(0.06)$ & $(0.04)$ & $(0.03)$ \\
\hline \multirow[t]{2}{*}{ Mother's secondary education } & $-0.11 * *$ & 0.00 & 0.04 & $-0.10 * * *$ \\
\hline & $(0.05)$ & $(0.05)$ & $(0.04)$ & $(0.03)$ \\
\hline \multirow[t]{2}{*}{ Father's university education } & 0.06 & 0.07 & 0.02 & $-0.12 * * *$ \\
\hline & $(0.07)$ & $(0.06)$ & $(0.05)$ & $(0.04)$ \\
\hline \multirow[t]{2}{*}{ Mother's university education } & -0.06 & 0.04 & 0.08 & -0.07 \\
\hline & $(0.05)$ & $(0.06)$ & $(0.06)$ & $(0.05)$ \\
\hline \multirow[t]{2}{*}{ Father's age } & 0.00 & 0.00 & 0.00 & 0.00 \\
\hline & $(0.00)$ & $(0.00)$ & $(0.00)$ & $(0.00)$ \\
\hline \multirow[t]{2}{*}{ Mother's age } & 0.00 & 0.00 & 0.01 & 0.00 \\
\hline & $(0.00)$ & $(0.01)$ & $(0.00)$ & $(0.00)$ \\
\hline \multirow[t]{2}{*}{ Father working part-/full-time } & $0.15 * * *$ & 0.00 & $0.08 *$ & 0.02 \\
\hline & $(0.05)$ & $(0.06)$ & $(0.04)$ & $(0.04)$ \\
\hline \multirow[t]{2}{*}{ Mother working part-/full-time } & 0.06 & $0.10 * * *$ & $0.08 * *$ & $0.06 * *$ \\
\hline & $(0.04)$ & $(0.04)$ & $(0.04)$ & $(0.03)$ \\
\hline \multirow[t]{2}{*}{ Household size } & -0.02 & -0.03 & -0.03 & $0.03 *$ \\
\hline & $(0.02)$ & $(0.02)$ & $(0.02)$ & $(0.01)$ \\
\hline \multirow[t]{2}{*}{ Age of youngest child } & -0.01 & 0.00 & 0.00 & $-0.01 * * *$ \\
\hline & $(0.01)$ & $(0.01)$ & $(0.00)$ & $(0.00)$ \\
\hline \multirow[t]{2}{*}{ Household owns dwelling } & 0.05 & 0.04 & $0.08 *$ & 0.00 \\
\hline & $(0.04)$ & $(0.04)$ & $(0.05)$ & $(0.04)$ \\
\hline \multirow[t]{2}{*}{ Computer at home } & 0.02 & -0.05 & 0.04 & -0.03 \\
\hline & $(0.11)$ & $(0.13)$ & $(0.03)$ & $(0.03)$ \\
\hline \multirow[t]{2}{*}{ Urban residence } & . & . & -0.01 & -0.02 \\
\hline & & & $(0.03)$ & $(0.03)$ \\
\hline \multirow[t]{2}{*}{ Constant } & -0.20 & $0.86 * * *$ & $-0.60 * * *$ & $0.54 * * *$ \\
\hline & $(0.34)$ & $(0.29)$ & $(0.19)$ & $(0.15)$ \\
\hline Fathers' hous. - Mothers' hous. & 0.148 & -0.0193 & 0.18 & 0.0553 \\
\hline P-value diff. & $(<0.01)$ & $(0.63)$ & $(<0.01)$ & $(0.10)$ \\
\hline Observations & 3,440 & 3,122 & 3,959 & 3,686 \\
\hline Pseudo R-squared & 0.04 & 0.04 & 0.05 & 0.08 \\
\hline
\end{tabular}

Notes: Robust standard errors in parenthesis. The sample is restricted to include individuals who are reported to be son/daughter of the reference person of the household in the Multinational Time Use Study (MTUS) from Germany and Spain. Housework is measured in hours per day, and is defined as the sum of the time devoted to "cook, wash up", "housework", "odd jobs", "shopping" and "domestic travel." *Significant at the 90\% level **Significant at the $95 \%$ level ***Significant at the $99 \%$. 


\section{APPENDIX B: Distribution of housework time}

Figure B1. Distribution of housework time, children
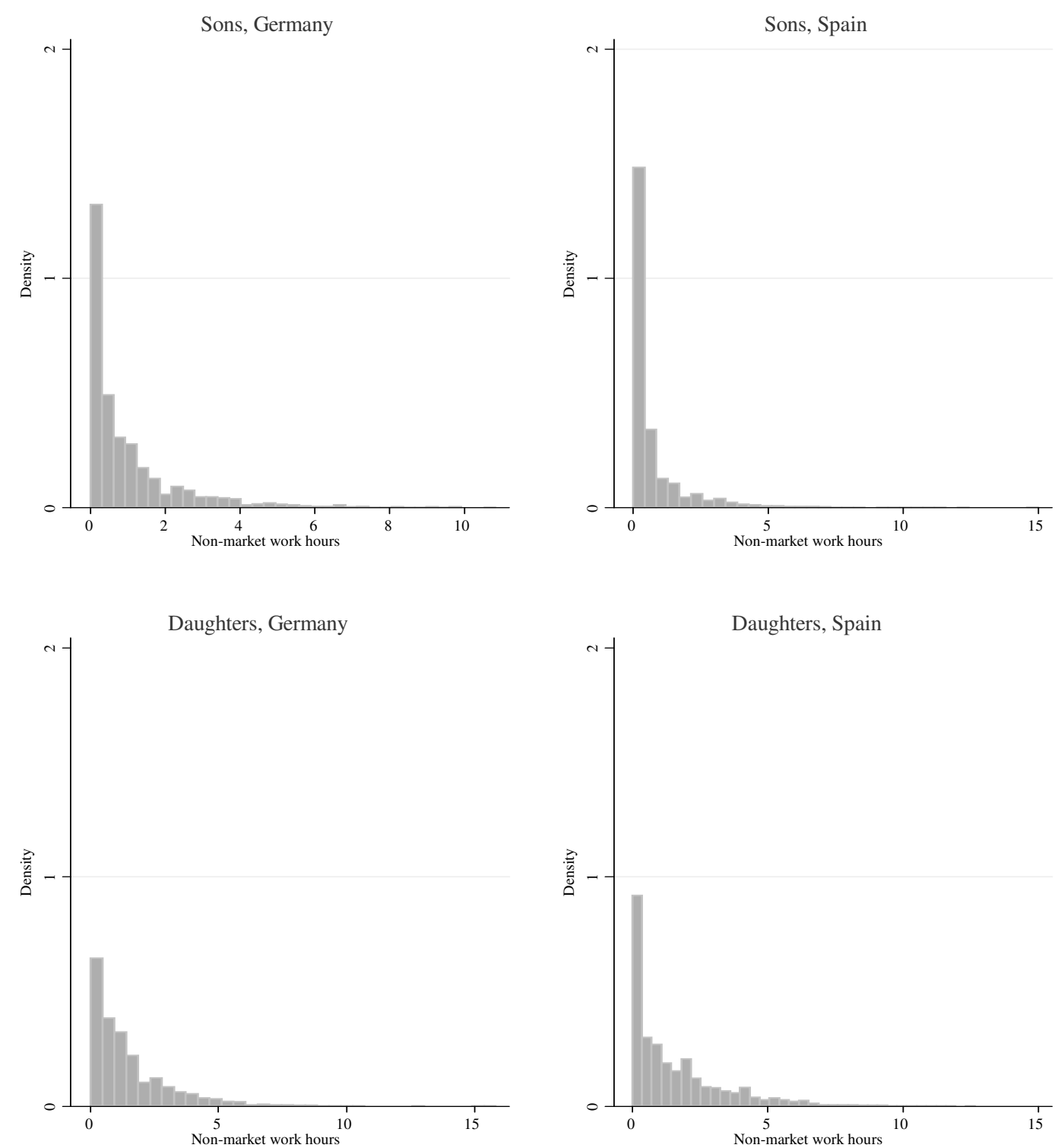

Note: Sample consists of individuals who are 10 years of age or older who are reported as being a child in the household, and living with two heterosexual parents, in Germany and Spain. We include fathers of those children. Housework includes the total time devoted to the following activities: "cook, wash up", "housework", "odd jobs", "shopping" and "domestic travel", and is measured in (log) hours per day. 
Figure B2. Distribution of housework time, parents
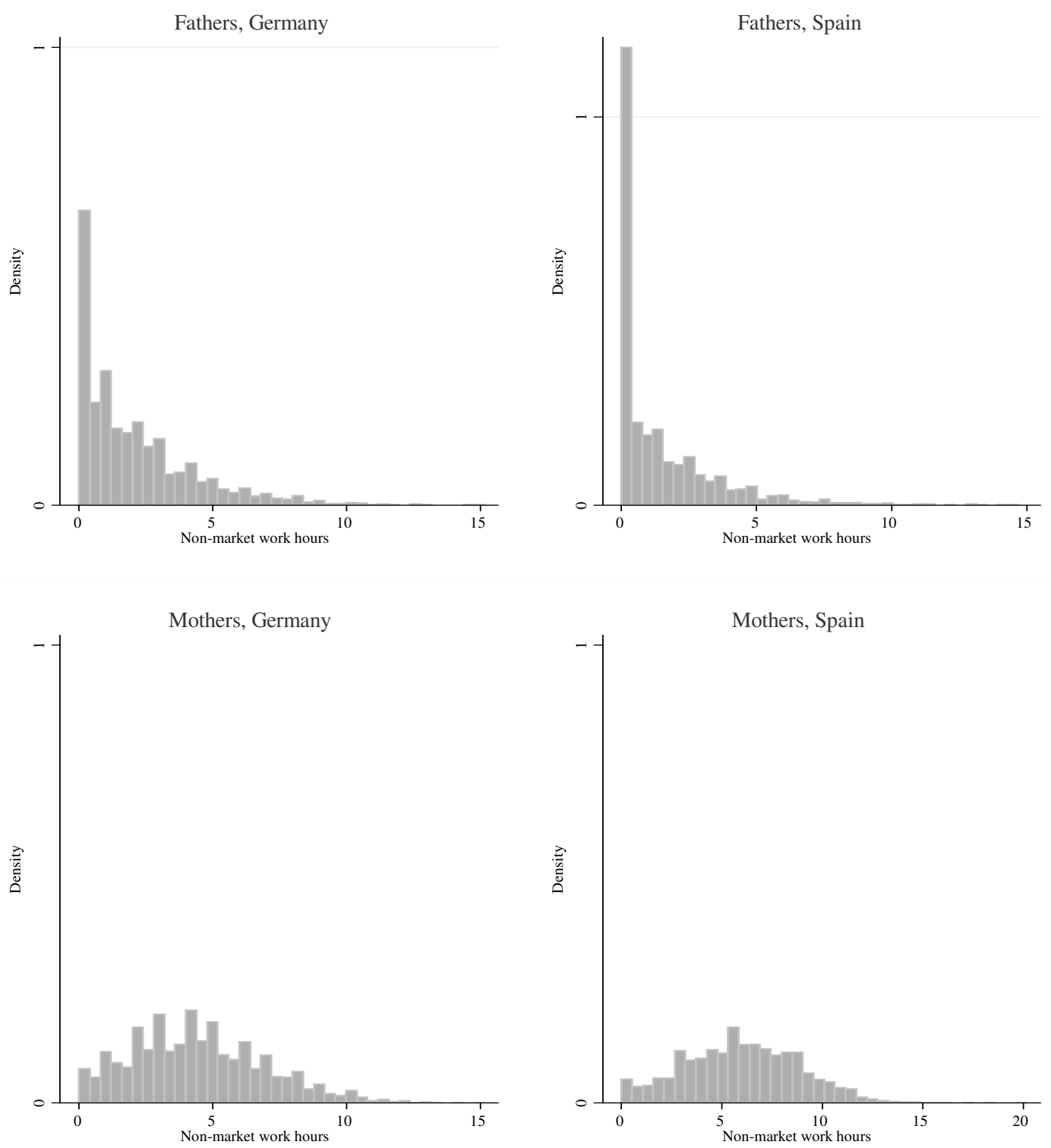

Note: Sample consists of individuals who are 10 years of age or older who are reported as being the reference person/spouse of reference person in household, living in heterosexual couples with at least one child, in Germany and Spain. We include mothers of those children. Housework includes the total time devoted to the following activities: "cook, wash up", "housework", "odd jobs", "shopping" and "domestic travel", and is measured in (log) hours per day. 